\title{
Current Trends of Enterococci in Dairy Products: A Comprehensive Review of Their Multiple Roles
}

\author{
Maria de Lurdes Enes Dapkevicius ${ }^{1,2, *(\mathbb{D}}$, Bruna Sgardioli ${ }^{1,2}\left(\mathbb{0}\right.$, Sandra P. A. Câmara ${ }^{1,2}$, Patrícia Poeta ${ }^{3,4}$ \\ and Francisco Xavier Malcata ${ }^{5,6, *}$ \\ 1 Faculty of Agricultural and Environmental Sciences, University of the Azores, \\ 9700-042 Angra do Heroísmo, Portugal; brunasgardioli@gmail.com (B.S.); \\ sandra.pa.camara@uac.pt (S.P.A.C.) \\ 2 Institute of Agricultural and Environmental Research and Technology (IITAA), University of the Azores, \\ 9700-042 Angra do Heroísmo, Portugal \\ 3 Microbiology and Antibiotic Resistance Team (MicroART), Department of Veterinary Sciences, \\ University of Trás-os-Montes and Alto Douro (UTAD), 5001-801 Vila Real, Portugal; ppoeta@utad.pt \\ 4 Associated Laboratory for Green Chemistry (LAQV-REQUIMTE), University NOVA of Lisboa, \\ 2829-516 Lisboa, Portugal \\ 5 LEPABE—Laboratory for Process Engineering, Environment, Biotechnology and Energy, \\ Faculty of Engineering, University of Porto, 420-465 Porto, Portugal \\ 6 FEUP-Faculty of Engineering, University of Porto, 4200-465 Porto, Portugal \\ * Correspondence: maria.ln.dapkevicius@uac.pt (M.d.L.E.D.); fmalcata@fe.up.pt (F.X.M.)
}

check for updates

Citation: Dapkevicius, M.d.L.E.; Sgardioli, B.; Câmara, S.P.A.; Poeta, P.; Malcata, F.X. Current Trends of Enterococci in Dairy Products: A Comprehensive Review of Their Multiple Roles. Foods 2021, 10, 821. https://doi.org/10.3390/ foods10040821

Academic Editors: Esther Sendra and Jordi Saldo

Received: 5 March 2021

Accepted: 31 March 2021

Published: 10 April 2021

Publisher's Note: MDPI stays neutral with regard to jurisdictional claims in published maps and institutional affiliations.

Copyright: (c) 2021 by the authors. Licensee MDPI, Basel, Switzerland. This article is an open access article distributed under the terms and conditions of the Creative Commons Attribution (CC BY) license (https:// creativecommons.org/licenses/by/ $4.0 /)$

\begin{abstract}
As a genus that has evolved for resistance against adverse environmental factors and that readily exchanges genetic elements, enterococci are well adapted to the cheese environment and may reach high numbers in artisanal cheeses. Their metabolites impact cheese flavor, texture, and rheological properties, thus contributing to the development of its typical sensorial properties. Due to their antimicrobial activity, enterococci modulate the cheese microbiota, stimulate autolysis of other lactic acid bacteria (LAB), control pathogens and deterioration microorganisms, and may offer beneficial effects to the health of their hosts. They could in principle be employed as adjunct/protective/probiotic cultures; however, due to their propensity to acquire genetic determinants of virulence and antibiotic resistance, together with the opportunistic character of some of its members, this genus does not possess Qualified Presumption of Safety (QPS) status. It is, however, noteworthy that some putative virulence factors described in foodborne enterococci may simply reflect adaptation to the food environment and to the human host as commensal. Further research is needed to help distinguish friend from foe among enterococci, eventually enabling exploitation of the beneficial aspects of specific cheese-associated strains. This review aims at discussing both beneficial and deleterious roles played by enterococci in artisanal cheeses, while highlighting the need for further research on such a remarkably hardy genus.
\end{abstract}

Keywords: dairy Enterococcus; starter culture; adjunct culture; protective culture; probiotics; opportunistic pathogen; pathogenicity determinants; antimicrobial resistance

\section{Introduction}

Enterococci are part of the subdominant microbiota of many artisanal cheeses [1] where they play an important role in the development of sensorial properties [1], help modulating the cheese microbiota [2] and may play a role in controlling pathogenic as well as deterioration microorganisms [3]. Their evolutionary history has primed them to resist (harsh conditions), adapt (to stress), and persist (in difficult environments). It has endowed this genus of commensal gut bacteria with plastic genomes and a notable capacity to trade genes by horizontal transfer events, both of a homologous and heterologous nature [4]. The adaptation to their hosts provided them the opportunity to become important opportunistic pathogens [4]; the ability to easily acquire genes by horizontal transfer allowed them 
to build up a considerable resistome [5], as well as several putative determinants of virulence [6]. On the other hand, enterococcal strains have been used as adjunct cultures, probiotics and may have beneficial effects upon several aspects of their human hosts health [7]. The impact of the enterococcal microbiota of artisanal cheeses on the health of their hosts is still the object of debate, despite the wealth of knowledge gathered in recent years on their presence, technological properties, potential health benefits, antibiotic resistance, and carriage of virulence factors [7]. Due to the uncertainty on their safety, enterococci do not possess QPS status in the EU and are not Generally Regarded as Safe (GRAS) in the USA. The lack of a recognized safety status as a genus has hampered their use as industrial food cultures, despite their potential benefits [8]. A better perception of their roles in the cheese system is required to both eventually allow for their industrial use and to understand their potential role as reservoirs of genetic determinants of antibiotic resistance and virulence. This review focuses on enterococci in artisanal cheeses, with the aim of thinking over their role(s) in this setting and exploring their current potentialities.

\section{The Genus Enterococcus-A Bacterial Group That Has Evolved for Resistance}

As a genus, enterococci have a relatively short history, most of which intertwined with that of other Gram-positive cocci, especially streptococci. The terms "streptococci" and "enterococci" first appeared during the Golden Age of Microbiology. "Streptococcos" has been employed for the first time in 1874, by Billroth [9], a contemporary of Louis Pasteur, to describe cocci arranged in chains that he observed in wounds. A decade later, streptococci were described as a genus, in Rosenbach's work on bacteria from suppurated wounds [10]. The first mention to the term "enterococcus" occurred less than 20 years later, when Thiercellin \& Jouhaud [11] reported isolating saprophytic, potentially pathogenic cocci from the human intestines. These new cocci were then thought to be part of the Streptococcus genus, and received the species epithet of faecalis [12]. Thirty years later, when Rebecca Lancefield published her serological classification of streptococci [13] and, subsequently, when James Sherman proposed division of streptococci into four groups [14], enterococci emerged as a separate group of "streptococcal lineages"; however, they would not be afforded the status of genus on their own until the mid-80s, when, based on molecular biology approaches, Karl Schleifer and Renate Kilpper-Bälz [15] proposed that the Grampositive cocci belonging to Lancefield's group $\mathrm{D}$ constitute, in fact, a genus, and named it after Thiercellin \& Jouhaud's cocci. At that time, only two species-Enterococcus faecalis and Enterococcus faecium - were assigned to the newly proposed genus. Presently, at the doorstep of the third decade of the new millennium, it encompasses close to 60 validly published species with correct name [16].

The association between enterococci and the human intestinal habitat has been established since the early works of Thiercellin \& Jouhaud [11]. More recently, research by Lebreton et al. $[4,17]$ has shown that enterococci are indeed a native enteric genus that has colonized from there a variety of human- and non-human-related habitats. Their ability to colonize these very diversified ecological niches stemmed from their evolutionary history, which has been hypothesized to have started $500 \pm 130.5 \mathrm{Myr}$, driven by terrestrialization of the animal hosts that sheltered the enterococcal ancestors [17]. Based on $16 \mathrm{~S}$ rRNA data, enterococci seem to have arisen from Vagococcus-like ancestors, which in turn stemmed out of the Carnobacteriacea branch of the bacterial tree of life. Carnobacteria and Vagococcus remained associated with marine hosts [17], whereas most enterococci relate to the gut of terrestrial animals (mammals, birds, reptiles, and insects) [17-19]. As a result of their evolution towards hardiness, members of this genus have been found in soils [20,21], waters [22], plants [21,23], hospital environments [24], foods [8,25] and feeds [26,27], further to their association with human and animal microbiota. Enterococci do not sporulate; hence, their persistence in these seemingly hostile environments stems, in part, from their ability to enter a viable, non-culturable state [28], their notable resistance to starvation, and their capacity to withstand desiccation [17]. The plasticity of the enterococcal genome granted them not only the ability to colonize a wide range of niches, but also capacitated them to 
play a wide range of roles in these environments-as well as in their human hosts-where they range from harmless commensals, through opportunistic pathogens, to probiotic bacteria [29].

\section{Raw Milk as a Source of Enterococci for Dairy Products}

Lactic acid bacteria are part of the core, mesophilic/psychrotrophic microbiota of raw bovine milk [30,31]. Although lactococci, lactobacilli, and streptococci may reach populations in the order of $10^{4} \mathrm{CFU} \mathrm{mL}{ }^{-1}$ in raw milk, the numbers of leuconostocs and enterococci reach only $10^{3} \mathrm{CFU} \mathrm{mL}^{-1}$ [30].

Enterococci may be present to large numbers in dairy products (up to $10^{8} \mathrm{CFU} \mathrm{g}^{-1}$ ) [32]. They are among the most common lactic acid bacteria in raw milk [24], which they access from dairy environment, animals, and humans [32-35]. Despite their relation to the intestinal microbiota of humans and dairy animals, fecal contamination does not seem to play an important role upon entrance of enterococci into the dairy production chain. The milking equipment has instead been regarded as their major source in raw milk [36]. The work by Gelsomino et al. [34] has demonstrated that the milking machine and the bulk tank are important sources of enterococci for milk and dairy products. The milking environment was found to be the source of vancomycin-resistant enterococci (VRE), rather than the animals [37]. Mastitis can also be a source of multidrug-resistant enterococci [38]. The season of the year may also play a role in modulating the enterococcal diversity in raw milk [39].

Raw milk may, therefore, serve as a source of enterococci for dairy products, even when pasteurization is applied during processing a posteriori. There are indeed reports of enterococci surviving pasteurization temperatures [40]. Their thermal resistance, however, is highly variable and species-dependent, with $z$ values ranging from 5.0 (E. faecalis) to $9.8^{\circ} \mathrm{C}$ (E. hirae) [41]. The thermal resistance of enterococci depends also on the growth phase and previous thermal history of the cells [42]; hence, the enterococcal microbiota in pasteurized milk differs from that of raw milk. Although Enterococcus durans tends to predominate in the former, the most prevalent enterococcal species in the latter is E. faecalis [39]. Besides their thermoduric character, post-treatment recontamination also explains the presence of enterococci in pasteurized milk products, such as cheese [32], with biofilms on milk-contact surfaces acting as a potential source of high numbers of bacteria $[43,44]$.

Enterococcus faecalis, E. faecium, E. durans, E. hirae, as well as (albeit infrequently) E. saccharominimum and E. italicus, have been isolated from the raw milk of cows, goats, and sheep (Figure 1) [31,36,38,39,41,45-64]. Additionally, E. dispar, E. malodoratus, E. pseudoavium and E. gallinarum have been isolated both in cow's and in ewe's milk. E. casseliflavus, E. mundtii, E. aquamarinus, E. asini, E. saccharolyticus, E. sulfureus, and E. raffinosus have been described only in cow's milk, whereas E. vikkensis was found just in ewe's milk. It is worth keeping in mind, however, that the apparently lesser diversity of enterococcal species in goat's and sheep's milk when compared to cow's milk may merely reflect the much fewer studies that focused on the former. 


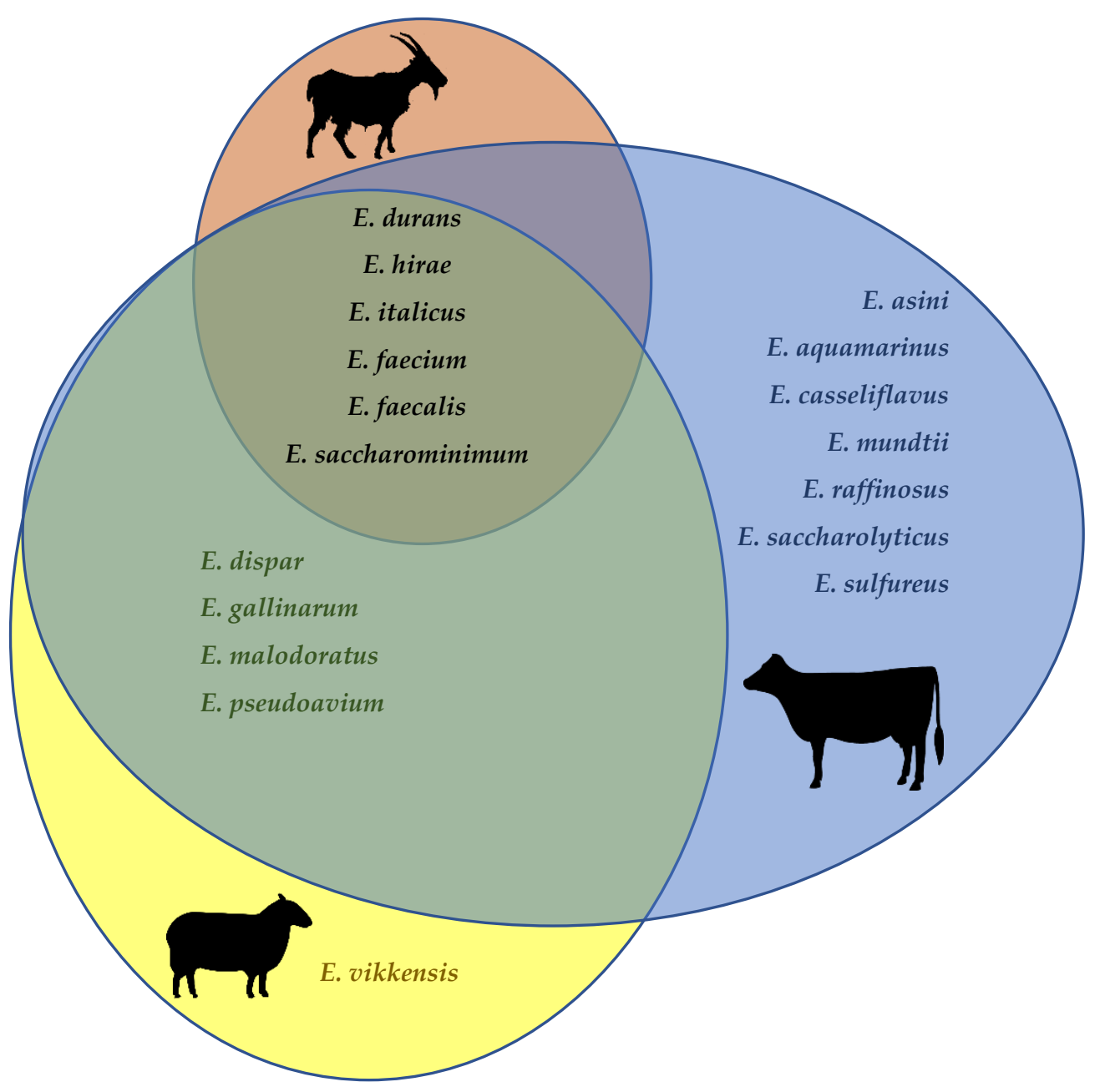

Figure 1. Enterococcal species described to date in raw cow's, goat's, and ewe's milk [31,35,38,39,41,45-64].

Several of the enterococcal species described in raw milk (e.g., E. faecalis, E. faecium and E. mundtii) are known to include strains that produce bacteriocins. Therefore, enterococci might play a role in modulating the milk microbiota, as well as the bacterial communities within dairy products, thus contributing both to their safety and to their sensorial properties [65]. Several enterococcal species from raw milk have demonstrated important technological properties with impact upon the sensorial properties of dairy products, such as diacetyl production, autolytic activity, proteolytic activity $[31,66]$ and lipolytic activity [67], as well as probiotic potential [68,69].

\section{The Enterococcal Microbiota of Artisanal Cheeses}

Nineteen enterococcal species have been described in artisanal cheeses so far-E. avium, E. casseliflavus, E. devriesei, E. durans, E. faecalis, E. faecium, E. gallinarum, E. gilvus, E. hirae, E. italicus, E. lactis, E. malodoratus, E. mundtii, E. pallens, E. pseudoavium, E. ratti, E. saccharominimus, E. sulfureus, and E. villorum (Table 1) [37,73,75-78,91-93,95,98-102,107,111,116-170]; they correspond to ca. one third of the species recognized at present in this genus. In many cheese varieties, the most prevalent enterococcal species are E. faecalis and E. faecium-and, to a lesser extent, E. durans [32]. It is, however, important to note that cheaper cultureindependent methodologies did not become widely available until recently, and this may have limited the number of species found so far. In the future, a growing accessibility to such methodologies may lead to reports on presence of other species, and even to discovery of novel enterococci in cheese. 
Table 1. Enterococcal species identified in European artisanal/traditional cheese varieties.

\begin{tabular}{|c|c|c|c|c|c|}
\hline Cheese (Type *) & Country & Milk Species/Treatment & Maturation Time & Enterococcal Species & Ref. \\
\hline Alberquilla (H) & Spain & Ewe/goat & - & E. devriesei, E. faecium & [117] \\
\hline Arzúa-Ulloa (S) & Spain & Cow (raw, pasteurized) & $6 \mathrm{mo}$ & E. durans & [122] \\
\hline Bitto $(\mathrm{H})$ & Italy & Cow (raw) & $>70 \mathrm{~d}$ & E. durans, E. faecalis, E. faecium, E. lactis & {$[73,123]$} \\
\hline Blue-veined cheese (MR) & UK & Cow (raw) & $3 \mathrm{mo}$ & E. durans, E. faecalis & [120] \\
\hline Bryndza (S) & Slovakia & Ewe (raw) & $\leq 14 \mathrm{~d}$ & E. casseliflavus, E. durans, E. faecalis, E. faecium, E. mundtii, E. pallens & [124-126] \\
\hline Cabrales (MR) & Spain & Cow/ewe/goat (raw) & $2-5 \mathrm{mo}$ & E. durans, E. faecalis & [122] \\
\hline Caciocavallo Palermit. (PF) & Italy & Cow (raw) & $4 \mathrm{mo}$ & E. casseliflavus, E durans, E. faecalis, E. gallinarum & {$[75,127]$} \\
\hline Calenzana (S) & Italy & Ewe/goat & $4-8 \mathrm{mo}$ & E. faecium, E. durans, E. hirae & [76] \\
\hline Canestrato Pugliese (H) & Italy & Ewe (raw) & $4 \mathrm{mo}$ & E. faecalis, E. faecium & [128] \\
\hline Casera Valtellina $(\mathrm{H})$ & Italy & Cow (raw) & $70 \mathrm{~d}$ & E. faecalis, E. faecium, E. gilvus & {$[129,130]$} \\
\hline Casín $(\mathrm{SH} / \mathrm{H})$ & Spain & Cow (raw) & $38 \mathrm{~d}$ & E. faecium & [91] \\
\hline Cazisolu (PF) & Italy & Cow (raw) & $1 \mathrm{mo}$ & E. durans, E. faecium, E. italicus, E. lactis & [131] \\
\hline Cueva de la Magahá $(\mathrm{H})$ & Spain & Goat (raw) & $8 \mathrm{mo}$ & E. devriesei, E. faecalis, E. faecium, E. hirae, E. malodoratus & [92] \\
\hline Danbo (SS) & Denmark & Cow & $18 \mathrm{wk}$ & E. faecalis, E. faecium & [132] \\
\hline Feta (S; B) & Greece & Ewe/goat & $2 \mathrm{mo}$ & E. canis, E. faecalis, E. faecium & [133] \\
\hline Fiore Sardo $(\mathrm{H})$ & Italy & Ewe (raw) & $9 \mathrm{mo}$ & E. durans, E. faecalis, E. faecium & [77] \\
\hline Fontina (SS) & Italy & Cow (raw) & $\leq 9 \mathrm{mo}$ & E. durans, E. faecalis, E. faecium, E. hirae & {$[48,134,135]$} \\
\hline Fossa $(\mathrm{H})$ & Italy & Cow/ewe & $1-3 \mathrm{mo}$ & E. durans, E. faecium, E. faecalis & [136] \\
\hline Fresh cheese $(F)$ & Croatia & Cow (pasteurized) & none & E. durans, E. faecium, E. hirae, E. ratti, E. villorum & [137] \\
\hline Galotyri (F) & Greece & Ewe/goat & none & E. durans, E. faecalis, E. faecium & [98] \\
\hline Genestoso (S) & Spain & Cow (raw) & $20-30 \mathrm{~d}$ & E. faecalis & [138] \\
\hline Graviera $(\mathrm{H})$ & Greece & Ewe/goat (thermized) & $3 \mathrm{mo}$ & E. durans, E. faecalis, E. faecium, E. hirae & {$[99,100]$} \\
\hline Hervé (S) & Belgium & Cow (raw) & $63 \mathrm{~d}$ & E. casseliflavus, E. faecalis, E. faecium & [140] \\
\hline Idiazábal-type (S; Smk) & Spain & Ewe (raw) & $70-72 \mathrm{~d}$ & E. durans, E. faecalis, E. faecium, E. casseliflavus, E. hirae, E. gallinarum & [37] \\
\hline Istrian $(\mathrm{H})$ & Croatia & Ewe (raw) & $3 \mathrm{mo}$ & E. faecalis, E. faecium, E. italicus, E. saccharominimus, E. sulfureus & [141] \\
\hline Kalathaki Lemnou (S) & Greece & Ewe/goat (raw) & $3 \mathrm{mo}$ & E. durans, E. faecalis, E. faecium, E. gilvus & [101] \\
\hline Livanjski (SH) & Bos.-Herz. & Cow/ewe (raw) & $1-2 \mathrm{mo}$ & E. durans, E. faecalis, E. faecium, E. gilvus, E. hirae, E. lactis, E. malodoratus & [95] \\
\hline Manchego $(\mathrm{SH} / \mathrm{H})$ & Spain & Ewe (raw, pasteurized) & 2-24 mo & E. avium, E. faecalis, E. faecium, E. hirae & [142] \\
\hline Maroilles (S) & France & Cow (raw) & $\leq 4 \mathrm{mo}$ & E. devriesei & [143] \\
\hline Melichloro (H) & Greece & Ewe/goat (raw) & $4-6 \mathrm{~d}$ & E. avium, E. durans, E. faecium, E. pseudoavium & [101] \\
\hline Montasio (SH) & Italy & Cow (raw) & $2-5 \mathrm{mo}$ & E. durans, E. faecalis, E. faecium, E. gallinarum & {$[78,79]$} \\
\hline Mozzarella (F; PF) & Italy & Cow (raw) & fresh & E. faecalis, E. sulfureus & [144] \\
\hline Nostrano (S) & Italy & Cow (raw) & $8 \mathrm{mo}$ & E. faecalis & [80] \\
\hline Nostrano di Primiero (S) & Italy & Cow (raw) & $2 \mathrm{mo}$ & E. faecalis, E. faecium & [81] \\
\hline Oscypek (SH; Smk) & Poland & Ewe (raw) & $5-18 \mathrm{~d}$ & E. durans, E. italicus & [145] \\
\hline Pecorino (central It.) $(\mathrm{H})$ & Italy & Ewe (raw) & $1-12 \mathrm{mo}$ & E. durans, E. faecalis, E. faecium & [146] \\
\hline Pecorino Abruzzese $(\mathrm{H})$ & Italy & Ewe (raw) & $3 \mathrm{mo}$ & E. durans, E. faecalis, E. faecium & [102] \\
\hline Pecorino Crotonese (H) & Italy & Ewe (r., therm., past.) & $4 \mathrm{mo}$ & E. faecalis & [147] \\
\hline Pecorino di Tramonti $(\mathrm{H})$ & Italy & Ewe (raw) & $1-3 \mathrm{mo}$ & E. durans, E. faecalis, E. faecium & [105] \\
\hline Pecorino Siciliano $(\mathrm{H})$ & Italy & Ewe (raw) & $0.5-6 \mathrm{mo}$ & E. durans, E. faecalis, E. faecium, E. hirae & {$[82,106,148]$} \\
\hline Picante $(\mathrm{SH})$ & Portugal & Ewe/goat (raw) & 4-6 mo & E. durans, E. faecalis, E. faecium, & [149-151] \\
\hline
\end{tabular}


Table 1. Cont

\begin{tabular}{|c|c|c|c|c|c|}
\hline Cheese (Type *) & Country & Milk Species/Treatment & Maturation Time & Enterococcal Species & Ref. \\
\hline Pico (SS) & Portugal & Cow (raw) & $21 \mathrm{~d}$ & E. faecalis, E. italicus, E. pseudoavium & {$[152-154]$} \\
\hline Provolone del Monaco (SH) & Italy & Cow (raw) & 6-12 mo & E. durans, E. faecalis, E. faecium & [83] \\
\hline Quesailla Arochena (NS) & Spain & Goat (raw) & $4 \mathrm{mo}$ & E. devriesei, E. faecalis, E. malodoratus & {$[118]$} \\
\hline Ragusano $(\mathrm{H} ; \mathrm{PF})$ & Italy & Ewe (raw) & $6 \mathrm{mo}$ & E. durans, E. faecalis, E. faecium, E. hirae & {$[148]$} \\
\hline Raw goat milk (SH) & Spain & Goat (raw) & $2 \mathrm{mo}$ & E. casseliflavus, E. durans, E. faecalis, E. faecium, E. gallinarum, E. hirae, E. italicus, E. lactis & [93] \\
\hline S. Jorge $(\mathrm{SH} / \mathrm{H})$ & Portugal & Cow (raw) & 6-12 mo & E. faecalis, E. faecium & {$[155]$} \\
\hline Saint-Nectaire (S) & France & Cow (raw) & $28 \mathrm{~d}$ & E. faecalis & [156] \\
\hline Salers $(\mathrm{SH})$ & France & Cow (raw) & $5 \mathrm{mo}$ & E. faecalis, E. faecium & [157-159] \\
\hline San Simón da Costa (SH;Smk) & Spain & Cow (raw) & $45-60 \mathrm{~d}$ & E. faecalis, E. sulfureus & [160] \\
\hline Semicotto caprine $(\mathrm{H})$ & Italy & Goat (raw) & $2 \mathrm{mo}$ & E. durans, E. faecalis, E. faecium, E. gallinarum, E. hirae & {$[85]$} \\
\hline Serbian artisanal (NS) & Serbia & Cow (raw) & - & E. durans, E. faecalis & [161] \\
\hline Serpa (SS) & Portugal & Ewe (raw) & $30 \mathrm{~d}$ & E. faecalis, E. faecium, E. hirae & [111] \\
\hline Serra (S) & Portugal & Ewe (raw) & $2-6 \mathrm{mo}$ & E. faecium & {$[162,163]$} \\
\hline Sokobanja (NS) & Serbia & Cow (raw) & $3 \mathrm{~d}$ & E. faecalis, E. faecium & [116] \\
\hline Stilton (MR) & UK & Cow (pasteurized) & $9-12 \mathrm{wk}$ & E. faecalis & [164] \\
\hline Taleggio (SS) & Italy & Cow (raw, past.) & $6-10 \mathrm{wk}$ & E. faecalis & [129] \\
\hline Terrincho (SS) & Portugal & Ewe (raw) & $1 \mathrm{mo}$ & E. casseliflavus, E. durans, E. faecalis, E. faecium, E. gallinarum & [165] \\
\hline Tetilla (S) & Spain & Cow (raw) & $1 \mathrm{mo}$ & E. durans, E. faecalis & [122] \\
\hline Tolminc $(\mathrm{H})$ & Slovenia & Cow (raw) & $2 \mathrm{mo}$ & E. faecalis & [166] \\
\hline Valsesia (SH) & Italy & Goat (raw) & $1-2 \mathrm{mo}$ & E. casseliflavus, E. durans, E. faecalis, E. faecium, E. gallinarum, E. gilvus & [86] \\
\hline Vlasina (S; B) & Serbia & Goat (raw) & $2 \mathrm{mo}$ & E. durans, E. faecalis, E. faecium & {$[168]$} \\
\hline White pickled (S; B) & Serbia, Croatia & Cow (raw) & $1-10 \mathrm{~d}$ & E. durans, E. faecalis, E. faecium & [169] \\
\hline Zlatar (SH; B) & Serbia & Cow (raw) & $2 \mathrm{mo}$ & E. faecalis, E. faecium & {$[170]$} \\
\hline
\end{tabular}

${ }^{*}$ H—hard; S—soft; SH—semihard; SS—semisoft; B—brined; F-fresh; MR—mold ripened; PF—pasta filata; Smk—smoked; NS—not specified. 


\section{The Technological Roles and Potentialities of Enterococci in Artisanal Cheeses}

In many artisanal cheeses, enterococci are part of the non-starter lactic acid bacteria (NSLAB) [1] and they have, in some instances, been used as components of experimental starter cultures $[32,142,171]$. As part of the NSLAB, their role in development of the typical sensorial characteristics has been documented for several artisanal cheese varieties, such as Armada, Caprino, Caciocavallo Palermitano, Cebreiro, Comté, Feta, Fontina, Majorero, Manchego, Mozzarella, Monte Veronese, Pico, Serra, Venaco (Southern Europe), Ras, Domiati (Egypt), and Izmir Tulum (Turkey) [32,127,142,153,171,172]. Although their role as NSLAB in the development of flavor has been demonstrated in many artisanal cheese varieties, their potential as cheese starters is much less clear. The main roles of a starter are to promote acidification and to take part in the initial steps of proteolysis, both of which are nuclear events in maturation and essential for development of unique cheese flavor, texture, and mouthfeel [173].

Isolation of enterococcal strains with good acidification properties from artisanal cheeses is not frequent, and comprised only 3.6 to $11.6 \%$ of the enterococcal isolates in Pico and Pecorino Abruzzese cheeses, respectively $[174,175]$. In several studies, the enterococci have been reported to exhibit a poor acidifying capacity, with only a small percentage of the isolates being able to produce acid enough for $\mathrm{pH}$ to drop below 5.0-5.2 upon incubation for $16-24 \mathrm{~h}$ at $37^{\circ} \mathrm{C}$ [176-178]. Some studies have shown that $E$. faecalis acidifies skim milk faster than E. faecium [85], but others have unfolded a wide inter-strain variation [179].

Casein degradation plays a role not only upon cheese flavor and texture, but also upon the accumulation of bioactive peptides, with potential health benefits, within the product matrix [7]. Caseinolytic strains have been isolated from artisanal cheeses to variable proportions $(17-95 \%)$ of the total enterococcal isolates $[153,174,175,180]$. The gelE gene, frequently regarded as a virulence factor, is involved in caseinolysis when the enterococci grow in dairy substrates. This gene is more frequent in E. faecalis than in other enterococcal species, in agreement with the higher proteolytic activity described for this species $[7,179,181,182]$. The expression of gelE has been associated, in recombinant enterococcal strains, to the production of milk protein hydrolysates with high inhibitory activity against the angiotensin-converting enzyme (ACE) [183]. In addition to the effect of the species, proteolysis in enterococci seems to also depend on the strain [7].

Enterococci are auxotrophic for several amino acids [184]. Therefore, their ability to grow and reach high populations in dairy matrices requires that they possess aminopeptidases to release essential amino acids from the casein-derived peptides as outcome of primary cheese proteolysis [185]. Casein degradation by enterococci is first accomplished by the extracellular Clp proteolytic complex. The resulting oligopeptides are then brought into the cell by several transport systems (Opp, Dpp, and DptT), where they are further degraded by aminopeptidases (Pep A, Pep B, Pep C, Pep F, Pep O, Pep Q, Pep S, Pep T and Pep V); they will eventually serve as a source of nitrogen for enterococcal growth, and function as precursors for flavor compounds [186]. Moreover, free amino acids can be converted to biogenic amines by enterococcal decarboxylase systems. Amino acid decarboxylation is activated in acidic environments, and may help the enterococcal cell maintain its $\mathrm{pH}$ homeostasis under such conditions. It may also support primary metabolism under nutrient depletion conditions [186]. Enterococci have often been identified as one of the main biogenic amine producers in cheese; synthesis of histidine decarboxylase, tyrosine decarboxylase, lysine decarboxylase, ornithine decarboxylase, and agmatine deiminase, as well as production of the corresponding biogenic amines (histidine, tyramine, 2-phenylethylamine, cadaverine, and putrescine) have been described for several species of this genus [187]. Nevertheless, aminopeptidase activity is a desirable trait for cheese starter cultures, since said enzymes release important flavor compounds and precursors thereof (i.e., small peptides and free amino acids) [173]. Furthermore, their activity may contribute to prevent flavor defects. Aminopeptidase P, for instance, contributes to reduce bitterness in cheese, by hydrolyzing proline-rich oligopeptides derived from proteolysis of 
casein [188]. The aminopeptidase activities of enterococci from artisanal cheeses seem to vary in a strain-, rather than species-dependent manner [142,172,174,175].

Given the intracellular location of aminopeptidases, the autolysis of enterococcal cells is important for cheese maturation, since it promotes contact of these enzymatic systems with their substrates, and consequently assists in flavor development by accelerating peptidolysis [189]. Starter autolysis has also been reported to assist in the control of bitterness defects in cheese [190]. Autolytic activity is highly dependent on the LAB strain [190]. Strong autolytic activity has been reported in enterococci from artisanal cheeses $[154,191]$, which has been linked to higher aminopeptidase activity in the case of cheese slurries [191].

Due to their generally low acidification capacity and limited proteolytic properties, enterococci are not often regarded as important elements of the primary starter cultures for cheesemaking [32]. They may, however, offer a promise either as adjunct [32,82,192,193] or as protective cultures $[32,176]$. Adjunct cultures are deliberately added to increase the intensity and help achieve a balanced cheese flavor. They are often selected among cheese NSLAB; hence, metabolic activities such as lipolysis, esterase activity, proteolysis, amino acid degradation, and citrate metabolism are of interest when screening for cheese adjunct cultures [194]. It has also been suggested that exopolysaccharide (EPS) production may be an interesting trait, especially for low-fat cheese varieties, where EPS would help improve textural properties and water holding capacity [195].

Lipid metabolism by the cheese microbiota gives a considerable contribution to the flavor and texture of many cheese varieties, via hydrolysis of the milk lipids retained in the cheese matrix and thereby releasing free fatty acids (FFA). These FFA are, in turn, metabolized to volatile compounds (methylketones and thioesters) that take part in cheese flavor. Although lipases act on emulsified milk fat, the esterases attack the dissolved lipid fractions [7]. Generally, cheese LAB (including the enterococci) are regarded as weakly lipolytic [7]; however, there are reports of strong lipolytic activity among enterococcal strains isolated from some cheeses [160,177], which may indicate that this trait is speciesand strain-dependent. The enterococci have been described as possessing a higher esterolytic activity than the remaining LAB genera $[7,160]$; however, their activity seems to be mostly limited to short-chain fatty acids [160].

Another activity of enterococci with an impact upon cheese flavor is their citrate metabolism, which releases several C-4, volatile compounds (e.g., diacetyl, acetoin, and butanediol). Furthermore, the $\mathrm{CO}_{2}$ released during citrate use takes part in the formation of the "eyes" (cavities) that are typical of such cheese varieties as Gouda and Danbo [196]. The production of diacetyl and, to a lesser extent, of acetoin have been described in enterococci from cheese $[142,153,175,197,198]$. Additionally, annotation of enterococcal genomes has revealed genes that encode for enzymes involved in acetaldehyde, diacetyl, and acetoin [186,199].

Some LAB can accumulate extracellular heteropolysaccharides; besides their protective functions, they take part in adhesion to surfaces and in biofilm formation, thus assisting EPS-producing strains in colonizing their environments, including their hosts' gastrointestinal tract (GIT) [200]. Due to their emulsifying, thickening, and anti-syneresis properties, these EPS can modify the texture and rheological properties of cheese [201]. The ability to produce EPS has been reported in enterococci from artisanal cheeses [202,203], and could be a positive trait for their use as adjunct cultures, especially in low-fat products [204].

Many strains of enterococci associated with cheese produce a wide diversity of bacteriocins (enterocins) bearing a broad-spectrum activity against several Gram-positive foodborne pathogens, including Listeria monocytogenes, Staphylococcus aureus, Bacillus cereus, clostridial endospores and vegetative cells, as well as other LAB [3,32,205]. Enterocin production may partly explain the success of enterococci in colonizing and reaching sizable numbers in cheese [3]. Enterocin diversity in enterococci is thought to stem from the remarkable ability of the bacteria in this genus to trade genetic material. For instance, the genetic determinants for enterocins EJ97 and AS-48 are encoded in conjugative, pheromone- 
responsive plasmids, thus making their transfer between enterococci fast and efficient [3]. As most bacteriocins, enterocins primarily target the cell membrane, where they form pores, thus leading to leakage of essential intracellular constituents while depleting transmembrane potential and/ or $\mathrm{pH}$ gradient $[206,207]$. One notable exception is enterolysin A, which attacks the cell wall [208]. In cheese, bacteriocin-producers may contribute to modulate the microbiota during ripening [2], promote the autolysis/increase cell permeability of starter and NSLAB (with the concomitant release of intracellular enzymes) [190,209,210], and inhibit pathogenic and deterioration microorganisms [58,211-214]. Enterocin production is, therefore, germane for adjunct cultures with protective functions. Several reports describe the experimental use of bacteriocinogenic E. durans, E. faecalis, E. faecium, and E. mundtii strains as cheese protective cultures [58,212-215]. However, some enterococci can act as human nosocomial, opportunistic pathogens; due to their propensity to trade genetic material, they may act as reservoirs of virulence and antibiotic-resistance genes $[214,216,217]$. Therefore, the genus has not been granted a Qualified Presumption of Safety (QPS) status. A thorough investigation of the safety-related phenotype and genetic determinants is indispensable for each enterococcal strain before equating its application in food. With these concerns in mind, the usage of purified or semi-purified enterocins as antimicrobial food additives has, in some instances, been recommended instead of its in situ production $[217,218]$.

\section{Enterococci and Potential Health Benefits of Dairy Products}

Besides contributing to the sensorial properties of artisanal cheeses, the action of enterococci on the protein fraction of milk, curd and maturating cheese may lead to accumulation of bioactive peptides with potential benefits for the consumers' health. Bioactive peptides are short protein fragments (2-20 amino acid residues) that can exhibit hormonal or drug-like effects $[219,220]$. Milk proteins are the most exploited source of peptides with antihypertensive, hypocholesteremic, antihyperglycemic, immunomodulatory, antimicrobial and antioxidant activity. Due to their proteolytic activity, several LAB (including enterococci) produce bioactive peptides when growing in milk [7].

The production of antihypertensive peptides by enterococci in milk fermentations has been demonstrated both in vitro $[7,221,222]$ and in animal models $[223,224]$. Torres-Llanez et al. [225] reported that fresh cheese containing E. faecium had high in vitro inhibitory activity against the angiotensin-converting enzyme (ACE); in another study, the consumption of a traditional Norwegian cheese (Gamalost) was found to decrease blood pressure in 128 subjects with a mean age of 51 years [226]. In the review by Baptista et al. [227], the presence of ACE-inhibitory peptides was described in Valdeón, Grana Padano, Maasdam, Gorgonzola, Cheddar and Parmigiano Reggiano. These very short peptides (3-7 amino acid residues) were all derived from $\beta$-casein [227]. Cheese maturation was shown to promote release of bioactive peptides [228,229], and so did in vitro digestion, thus confirming the potential of cheese as vehicle for their administration.

Enterocin production may provide a competitive advantage within the GIT to the producing strains, owing to their antimicrobial activity. Consequently, enterococcal strains that produce this type of antimicrobial peptides are better equipped to establish themselves in the GIT of the host, to directly inhibit pathogens and to modulate the host's gastrointestinal microbiota [230]. The potential for selected enterococci toward modulation of the GIT microbiota in the host, when administered orally, has been demonstrated in animal models [231,232].

Albano et al. [233] demonstrated that an E. lactis strain decreased the cholesterol concentration in broth and as part of a cheese adjunct culture, whereas oral administration of certain E. faecalis or E. faecium strains led to a significant decrease in serum cholesterol levels of hypercholesterolemic animal models [232,234]. In the case of E. faecium, cholesterol excretion was promoted; cholesterol degradation and transportation genes were up-regulated, while genes involved in cholesterol synthesis were down-regulated [234]. Translocation 
of the orally administered bacteria, which could unfold an invasive potential, was not observed and low-density cholesterol levels decreased in a mouse model [233].

The products of milk fermentation by $E$. faecalis displayed in vitro inhibitory activity against $\alpha$-glucosidase, an indication of their potential for control of hyperglycemia [7]. Evidence from a study in mice demonstrated that a probiotic $E$. faecium strain shows in vivo antihyperglycemic effects and decreases insulin resistance when administered in conjunction with food [233]. An E. faecalis strain from traditional Tunisian Rigouta increased by $28 \%$ the secretion of interleukin-10 in Caco-2/TC 7 cells, an indication of its immunomodulatory potential [235]. In a study by Graham et al. [7], milk fermented with E. faecalis strains from cheese exhibited a high total phenol content and radical scavenging activity.

Enterococci are among the several food-associated bacteria that can produce conjugated linoleic acid (CLA), a derivative of an essential fatty acid, linoleic acid, which has received considerable attention due to its potential health effects [236]. Kishino et al. [237] showed that enterococcal strains can produce high concentrations of CLA under laboratory conditions and Ross et al. [238] proposed use of CLA-producing LAB to manufacture novel, value-added cheeses.

The gut microbiome is now known to play an important role in the so-called gut-brain axis, and to impact their human host's mental health by several mechanisms, including production of neurotransmitters [239]. Enterococcus spp. [240] are known to produce serotonin in the gut, thus participating in the cross talk between these two organs. Enterococci are also capable of producing $\gamma$-aminobutyric acid (GABA) [80,241,242], a neurotransmitter possessing multiple health benefits beyond its impact upon mental health. Other GABAproducing LAB have been isolated from traditional, artisanal cheeses [241-243], but GABA production has not yet been reported in enterococci isolated from cheese.

The multiple, putative health benefits associated with enterococci, coupled with their ability to survive passage through the proximal part of the GIT and to colonize the host's gut, make this genus an interesting candidate for development of probiotic cultures. Because they harbor an underexploited, diverse microbiota [47], traditional, artisanal cheeses have been successfully screened for enterococcal strains with probiotic potential $[205,235,243-245]$. Enterococcal probiotics have, so far, met with limited commercial success, and only under the form of dietary supplements [246]; however, foods such as fresh cheese would also serve as suitable carrier for probiotic microorganisms $[247,248]$. The major constraints upon commercial application of enterococci in probiotic preparations and foods for human consumption arise from safety concerns, insufficient information on their safety-related properties and health benefits, and unfavorable regulatory environment [8]. Information on the safety significance of enterococcal traits (such as their adherence factors), concerns that they might act as reservoirs of virulence and antibioticresistance genes, their propensity to engage in horizontal gene transfer (both within their genus and with other bacteria), the need to further substantiate the health claims associated with potential probiotic candidates, and the lack of QPS/GRAS status make it very hard presently to successfully develop and place in the market an Enterococcus-based food product. The available data on safety and benefits of enterococci as probiotics are not sufficient to perform a thorough risk analysis. If enterococci, from cheese or other sources, are to be employed as probiotics, said knowledge gap must be bridged.

\section{Enterococci as Opportunistic Pathogens}

\subsection{General Aspects}

By the time that Thiercellin \& Jouhaud [11] applied the denomination "enterocoque" to intestinal commensal cocci, the first case of a human infection attributable to this genus was also described; however, the emergence of enterococci as problematic, opportunistic pathogens would come only in the late 1970s [219]. Despite their increasing importance as nosocomial opportunists, enterococci are not regarded as highly virulent, as they require an immunocompromised host for disease to happen [219]. In this type of hosts, they cause primarily urinary tract infections, but also nosocomial bacteremia, and intra-abdominal, 
pelvic, wound, and tissue infections. Meningitis and respiratory infections caused by enterococci are very rare [249]. Rather than being linked to high virulence, the success of the enterococci as nosocomial pathogens can be explained by their evolutionary history. While co-evolving with their hosts to adapt to terrestrial life, the enterococci became a hardy genus. They acquired a propensity to exchange genetic information with other bacteria that occupy the same habitats, so they developed streamlined, malleable genomes that enabled them to thrive even when faced with such environmental stress factors as antibiotic exposure that characterize modern healthcare facilities [17].

Mundy et al. [250] indicated 12 enterococcal species implicated in human infections: E. avium, E. casseliflavus, E. durans, E. faecalis, E. faecium, E. gallinarum, E. hirae, E. malodoratus, E. mundtii, E. pseudoavium, E. raffinosus, and E. solitarius. Of these, E. faecalis and E. faecium are the most prevalent; they represent ca. $75 \%$ of the clinical isolates [249]. E. faecalis is one of the so-called ESKAPE pathogens (E. faecium, S. aureus, Klebsiella pneumoniae, Acinetobacter baumannii, Pseudomonas aeruginosa, and Enterobacter spp.), a group of virulent, multiresistant microorganisms that account for most human nosocomial infections [251,252]. Infections by other enterococci, however, have been increasingly reported [219].

\subsection{Virulence Factors of the Enterococci}

Several virulence factors have been described in enterococci, mostly in E. faecalis and E. faecium [247]. Chajecka-Wierzchowska et al. [252] have classified the enterococcal virulence factors described so far in two groups: surface proteins that promote colonization of the host, and secreted metabolites that damage the host's tissues. In extracellular pathogens such as enterococci, the preferential adherence targets are components of the extracellular matrix (ECM) or the serum, such as collagen, fibronectin, and fibrinogen [253]. Although adhesion to the host is the first stage of the infection process, it cannot be exclusively regarded as a virulent feature; as commensals, enterococci also need to adhere to the intestinal epithelium to avoid being carried away by peristaltic movements [252]. Once they have successfully colonized the host, virulent strains of enterococci secrete histotoxic metabolites, thereby damaging the host's tissues. Virulence factors that promote adhesion (all of them surface proteins) include aggregation substance (AS), collagenbinding proteins (Accessory colonization factor, $\mathrm{ACE}$ in E. faecalis and $\mathrm{ACm}$ in E. faecium), cell wall adhesin (endocarditis specific antigen, Efa A), and enterococcal surface protein (Esp); whereas cytolysin (Cyl), gelatinase (gelE) and hyaluronidase (Hyl) are classified as part of the group of secreted toxins with negative effects upon the host's tissues [252].

AS refers to a group of highly homologous adhesins, encoded in large plasmids, that mediate efficient adhesion between bacteria, and facilitate plasmid exchange as an integral part of the enterococcal pheromone system [253]. These proteins play, therefore, a role in disseminating plasmids that encode determinants of antibiotic resistance, as well as other virulence factors (e.g., cytolysin) within a bacterial species [254]. Besides mediating adhesion between conjugating bacterial cells, AS also promotes adhesion to various types of host cells, such as renal tubular cells and intestinal epithelial cells, as well as to extracellular matrix (ECM) proteins [254]. AS is thought to play a role in biofilm formation by enterococci [247]. Furthermore, it has a protective action against the host's defense mechanisms. In E. faecalis, AS was demonstrated to promote opsonin-independent biding to human neutrophils, thus making the bacterium harder to kill by these defensive cells [255]. It can also promote binding to macrophages, thus increasing the survival time of E. faecalis inside these cells [255]. AS acts synergically with cytolysin, so $\mathrm{AS}^{+} / \mathrm{Cyl}^{+}$ strains exhibit increased mortality compared to isogenic strains that express only one of such genetic virulence determinants [245]. Genetic determinants for AS proteins have been found in E. faecalis and in E. faecium isolates; in clinical ones, they are more frequent in E. faecalis than in E. faecium strains [256-258]. Recently, the presence of asa1 has been described in E. gallinarum strains of food origin [259].

ACE has been associated with E. faecalis and is present in most clinical isolates of this species [260]. It belongs to the Microbial Surface Component Recognizing Adhesive 
Matrix Molecules (MSCRAMM) group of surface proteins with LPXTG (lysine-proline-any amino acid-threonine-glycine) [253]. It is structurally more similar to the first MSCRAMM discovered in Gram-positive bacteria-the Cna protein of S. aureus-than to the ACm protein of E. faecium [252]. It promotes colonization of the host by binding to ECM and participates in binding to type I and IV collagen and to laminin [253]. It is encoded in the ace gene; deletion of ace decreased virulence, and affected survival of E. faecalis inside the host's macrophages. This virulence determinant has been demonstrated to be involved in urinary tract infections [253] and in endocarditis [260]. E. faecium also possesses a collagen-binding protein $(\mathrm{ACm})$. Unlike $\mathrm{ACE}$, it only binds to collagen, not to lamin, and shows greater affinity towards collagen I than collagen IV [260].

EfaA is a potential virulence determinant, thought be involved in pathogen's adherence to the host's cells; however, knowledge of its role in enterococcal infections is still scarce [261]. It has been suggested that this protein plays a role in adhesion in endocarditis [262]. EfaA is encoded by efa $A_{f s}$ in E. faecalis strains and efa $A_{f m}$ in E. faecium strains [263].

Esp is the largest of the enterococcal proteins identified. Its structure is similar to that of several proteins of other Gram-positive bacteria, such as C- $\alpha$ in $\beta$-hemolytic Streptococcus agalactiae, R28 in Streptococcus pyogenes, and Bap in S. aureus. The latter is associated with biofilm formation [252], and its role therein has been duly demonstrated [264]. In biofilms, bacteria display higher resistance to antibiotics than in their planktonic form, and exchange of genetic material between bacterial cells is favored [265]. The genetic determinant of Esp (esp) is in a pathogenicity island, which also contains proteins responsible for antibiotic efflux [266]. The relation between carriage of esp, vancomycin and multiple antibiotic resistance has been demonstrated in E. faecium strains [267]. The mechanisms for transferring the esp differ between E. faecalis strains (chromosome-to-chromosome transmission) and E. faecium (integration into a conjugative plasmid) [268].

$\mathrm{Cyl}$ is one of the best characterized enterococcal virulence factors. It is a bacteriocintype exotoxin, with bactericidal activity against Gram-negative bacteria and hemolytic action against erythrocytes ( $\beta$-hemolysis), leukocytes and macrophages. The operon that encodes for $\mathrm{Cyl}$ is in mobile genetic elements, either in strongly conserved, pheromonedependent plasmids (such as pAD1), or within the same chromosomal pathogenicity island that contains the determinants for such other virulence factors as Esp or AS. It is widely spread and can be found in many enterococcal species (E. faecalis, E. faecium, E. avium, E. casseliflavus, E. cecorum, E. durans, E. gallinarum, E. malodoratus, and E. raffinosus) from clinical, animal and food origin [252,269].

The extracellular, zinc-dependent metalloendopeptidase Gel is encoded by gelE, which is in the enterococcal chromosome. It acts on elatine, elastin, collagen, and hemoglobin, and may play a role toward biofilm formation [252]. It occurs mostly in clinical and food strains of E. faecalis, but is only rarely found in E. faecium [263].

Hyl targets the mucopolysaccharides in the connective tissue and cartilage, thus promoting dissemination of enterococci within the host's tissues [252]. In clinical isolates, it occurs chiefly in E. faecium, and very seldom in certain E. faecalis strains [270]. It has also been found in strains of other species (E. casseliflavus, E. mundtii and E. durans) isolated from foods [252].

\subsection{Virulence Determinants in Enterococci from Foods}

Due to their importance as human opportunistic pathogens, more studies are available on the presence of genetic determinants of virulence in E. faecalis and E. faecium than on other enterococcal species. In most such studies, E. faecalis strains were found to carry a much higher number of genetic virulence determinants than E. faecium strains, both in clinical [258,264,271,272] and food strains [261,263,264,272], including those from traditional cheeses [102,271,273,274]. In many studies, genes that encode for adhesion factors (e.g., asa1/agg, esp and efa A) were highly prevalent among $E$. faecalis isolates from cheeses $[152,154,166,274-278]$ but could also be found in E. faecium isolates [102,203,276,278-280]. Much fewer studies exist on the prevalence of 
these genetic determinants in other enterococcal species isolated from cheeses. EfaA determinants (efaAfm and/or efaAfs) were found in E. casseliflavus [276], E. durans [275,276,280], E. gallinarum [275], E. hirae, and E. italicus [280]. AS determinants (agg/asa1) were found in E. durans, E. italicus [280], and E. avium [142]. The esp gene was found only in E. durans [280]. None of the non-faecalis, non-faecium isolates in these studies carried ace. In some studies, none of the E. casseliflavus, E. durans, E. gallinarum [168,273], and E. italicus [193,281] strains tested carried genetic determinants of adhesion.

In E. faecalis and E. faecium isolates from cheese, gelE has been frequently found $[102,142,152,166,203,235,274-277,280,282]$. The reported prevalence of Cyl determinants was lower than that of gelE in these two species [142,152,203], and presence of hyl was even rarer [203]. Studies on the carriage of genetic determinants for Cyl, Gel and Hyl by non-faecium, non-faecalis strains are scarce. The gelE gene has been described in E. casseliflavus [276], E. durans [275,280], E. hirae [142], and in one E. italicus strain [280]. Even less frequently reported was the existence of $\mathrm{Cyl}$ and Hyl determinants. Nieto-Arribas et al. [142] described presence of cylA in two isolates belonging to the E. avium and E. hirae species, and hyl in two E. avium strains.

The existing data on prevalence of the aforementioned virulence factors in enterococcal strains from cheese should be interpreted with care-especially in the case of non-faecalis, non-faecium isolates-since the number of studies available is low. Nevertheless, they suggest that in cheese enterococci, genetic determinants of adhesion proteins are common, whereas genetic determinants of histo- and cytotoxic metabolites, except for gelE, seem much less disseminated. Presence of adhesion determinants is not frequently regarded as an indication of pathogenic potential per se, but simply as an adaptation to life as commensal, by contributing to persistence of enterococci in the host's GIT [23,102,277,283,284]. Furthermore, no enterococcal infections have been traced to food sources [252], leading to a widespread perception that the enterococci from artisanal cheeses pose a very low risk to public health. Bearing in mind that sex pheromone determinants $(c p b, c o b, c c f)$ have been found in enterococci isolated from cheeses often with a high prevalence $[23,166,276,278,279]$, and that the genes encoding virulence factors are frequently located in pathogenicity islands or mobile elements that facilitate their dissemination even further [219], the possibility that cheeses may serve as a route for the transfer of virulence genes from their enterococcal reservoirs to the bacteria in the GIT of their consumers should not be discarded $[153,193,252,285,286]$. Further studies are needed not only to clarify the potential role of cheeses and their enterococci toward dissemination of virulence genes, but also to support strategies aimed at mitigating this problem. It is noteworthy that in two studies on traditional cheeses, a decrease in number of Enterococcus isolates harboring virulence determinants was observed towards the end of their 60-120 d-period of maturation [102,276]; this raises the question of whether other manufacture parameters could also influence the potential role of artisanal cheeses as reservoir of bacterial virulence genes within their enterococcal populations.

Because presence of virulence factors in enterococci is strain-dependent, a genus- or species-wide decision on their safety status has been hampered. The Scientific Committee of the European Food Safety Agency has accordingly decided not to grant them Qualified Presumption of Safety (QPS) [8], and neither has the US Food and Drug Administration granted them Generally Regarded as Safe (GRAS) status $[8,235]$. The lack of QPS/GRAS status significantly hinders application of enterococci as food cultures and conveys one more justification to why research on enterococcal safety-related traits is of utmost importance.

\section{Enterococci as Reservoirs of Antibiotic Resistance}

The evolutionary history of enterococci has primed them to colonize modern hospital environments, and cause infection in immunocompromised patients by endowing these bacteria with a notable resistance to environmental factors; this set of genetic determinants enables them to colonize efficiently their hosts, and a striking ability to trade genes with other bacteria, thus fostering their adaptation to the seemingly hostile conditions faced 
therein [219]. The ability to resist antibiotics, acquired during evolution of this genus, is one of the factors that explain the success of enterococci as nosocomial pathogens. Antibiotic resistance in enterococci was acknowledged even before they were recognized as a genus, and the first report on what is thought to have been an enterococcal infection was almost simultaneous with the coining of this bacterial epithet by Thiercelin and Jouhaud [282]. Because enterococci were no longer killed by many of the $\beta$-lactam antibiotics that are effective against other Gram-positive cocci, treatment of infections with these agents resorted to synergistic combinations of $\beta$-lactam antibiotics with aminoglycosides [219]. The emergence of high-level aminoglycoside resistance, a few years later, rendered this combination therapy ineffective, and promoted an antibiotic that had found little use so far-vancomycin - to the role of leading therapeutic agent against enterococcal infections by the late 1970s-early 1980s. The first reports on vancomycin-resistant enterococci (VRE) appeared in the 1980s, and every new antibiotic introduced afterward to replace vancomycin as a last-line therapy has been followed by reports of resistant enterococcal strains (Figure 2), thus rendering it ineffective for this purpose. At present, multidrug-resistant enterococci are a leading cause of nosocomial infections, thus raising challenges for their treatment and constituting a heavy social burden [282].

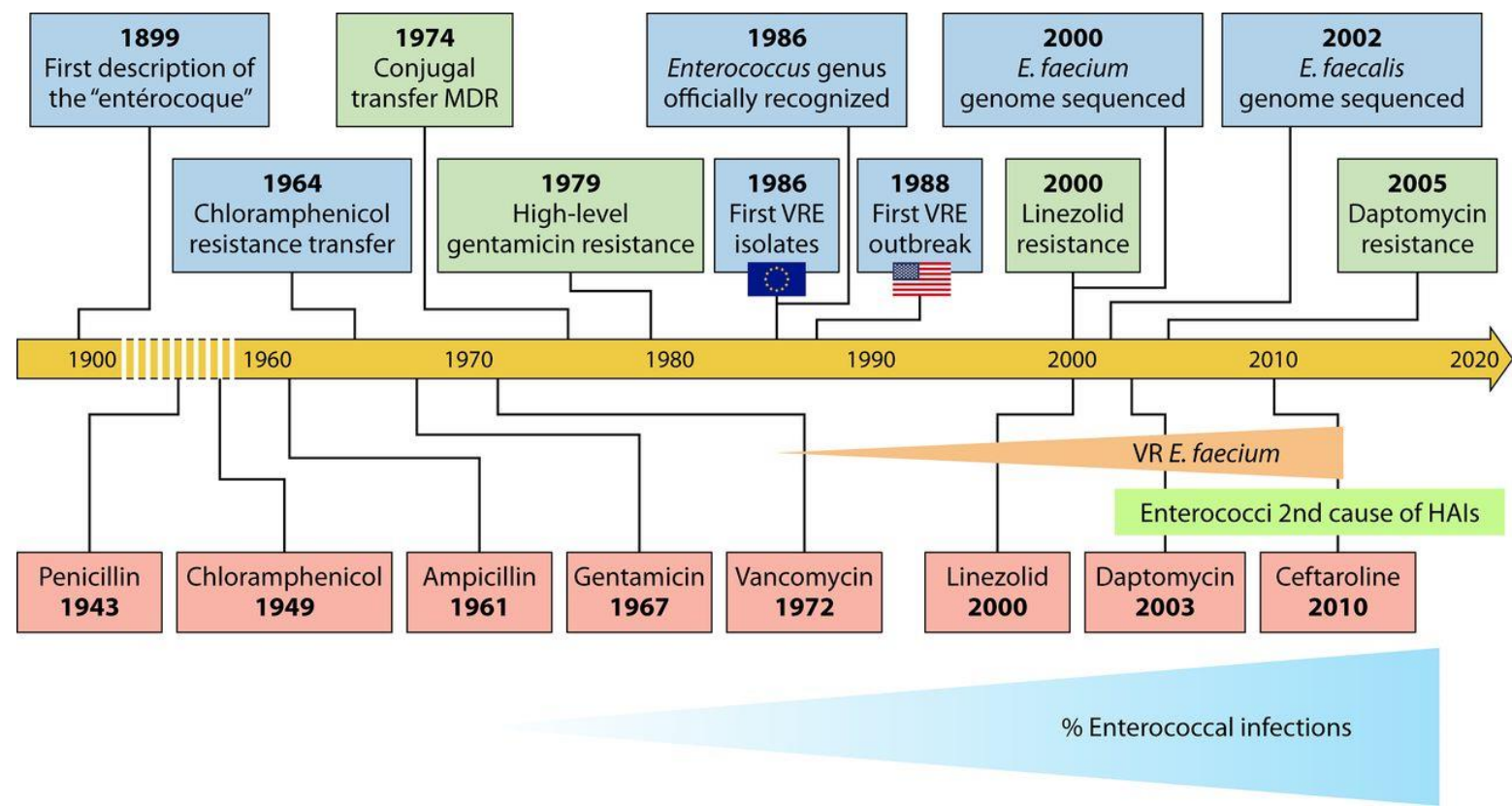

Figure 2. History of enterococci as human pathogens, with emphasis on emergence of antibiotic resistance in the genus. HAIs: hospital acquired infections. Reprinted with permission from García-Solache et al. [219]. (License No. 5016471445387).

Early on, E. faecalis was the causative agent of most enterococcal infections. However, E. faecium has emerged during the last two decades as leading agent of multidrug-resistant enterococcal infections [286]. One possible explanation for this shift lies on the emergence of VRE. From the earliest reports, most clinical VRE strains belonged to the E. faecium species. The success of VR E. faecium in penetrating and colonizing hospitals has led to a situation that can presently be described as endemic. Factors that led to this endemicity in hospitals have been identified as clonal dissemination of particular strains of said pathogen, selective pressure exerted by prolonged antibiotic regimens, and limitations of usual infection control strategies against this unusually hardy pathogen [250]. In a comparative genomics study by Lebreton et al. [4], it was demonstrated that the currently circulating multidrug resistance (MDR) strains that infect humans belong to a clade that probably diverged from E. faecium strains that adapted to other animal hosts ca. 80 years ago, at a time when antibiotics were introduced as therapeutic agents. The genomes of this clade 
are highly malleable, thanks to an increase in mobile genetic elements, to hypermutability, and to metabolic alterations [287].

Bacterial resistance to antibiotics is usually classified as either intrinsic or acquired, with the former resistance being encoded by chromosomal genes present in all members of a species. This resistance is likely due to selective pressures that all members of an enterococcal species experience when colonizing the gut, namely their need to survive innate defenses of the host (consubstantiated in the action of lysozyme, phospholipase C, antimicrobial peptides, or bile-like detergents). It may also result from exposure to selective pressures outside the host, such as resistance to starvation and desiccation [17]. Conversely, acquired resistance is encoded either by genes located in such mobile elements such as plasmids and transposons, or is a result of mutations. The most common transmissible elements implicated in exchange of genetic determinants of resistance in enterococci are the $\operatorname{Tn} 3$ family transposons, such as Tn917 (resistance to macrolides-lincosamide-streptogramin B, MLSB antibiotics), Tn1546 (resistance to glycopeptide resistance), and conjugative transposon Tn916 (minocycline and tetracycline) [285]. Plasmids are abundant in enterococci and entail another important contribution to their genomic plasticity. Transmission of antibioticresistance determinants has been mediated chiefly by pheromone-responsive plasmids and broad host range plasmids of the incompatibility group 18 type (Inc. 18 type). Pheromoneresponsive plasmids are found mainly in E. faecalis and are highly efficient in transmitting genetic information within this species. Broad host range plasmids can mediate transfer of genetic information between bacteria, but not so efficiently as pheromone-responsive plasmids. Broad host range plasmids of the Inc. 18 type have been implicated in transfer of vancomycin resistance determinants from enterococci to methicillin-resistant S. aureus [288]. Oftentimes, clinical isolates contain multiple plasmids and transposons [289].

Bacteria can acquire genetic determinants of antibiotic resistance via spontaneous mutations, yet development of multidrug resistance (MDR) by this mechanism only would require a long time. By contrast, horizontal gene transfer (HGT) allows bacteria exchange antibiotic-resistance genes in a more time-efficient manner, by promoting collaboration of the whole bacterial community toward development of MDR [290]. Bacteria can gain mobile elements by conjugation or transduction; such genetic transfer is more likely to occur in environments where bacteria are present to large numbers and undergo selective pressure [291]. Although this process is not yet well-studied, the gut microbiota probably becomes enriched in intrinsically resistant enterococci and other overtly resistant species (many of which carry mobile elements) under antibiotic selective pressure, and this contributes to the ability of enterococci serve as "trade hubs" for a variety of antibiotic-resistance plasmids and transposons [282].

Enterococci developed effective mechanisms for HGT, and this explains (at least in part) the increasing dissemination of antibiotic-resistance genes within this genus [281] Conjugation is the main HGT mechanism in enterococci. Natural transformation as a means of acquiring mobile genetic elements by enterococci has not yet been described, nor is the role of transduction clear yet [292].

The genomic plasticity of the enterococcal genome, both in clinical and food isolates, is due in part to lack of a functional CRISPR system [293,294], complemented by an efficient plasmid transfer system that involves production of pheromones. As a result, they have a great capacity to acquire and spread genetic traits, including resistance genes [295]. Enterococci have indeed been found to trade genetic determinants both in vitro and in vivo, not only within their own genus, but also with bacteria belonging to other genera with whom they share habitats, viz. other LAB (lactobacilli, lactococci), streptococci, staphylococci, Listeria, and bifidobacteria [5] (Figure 3). 


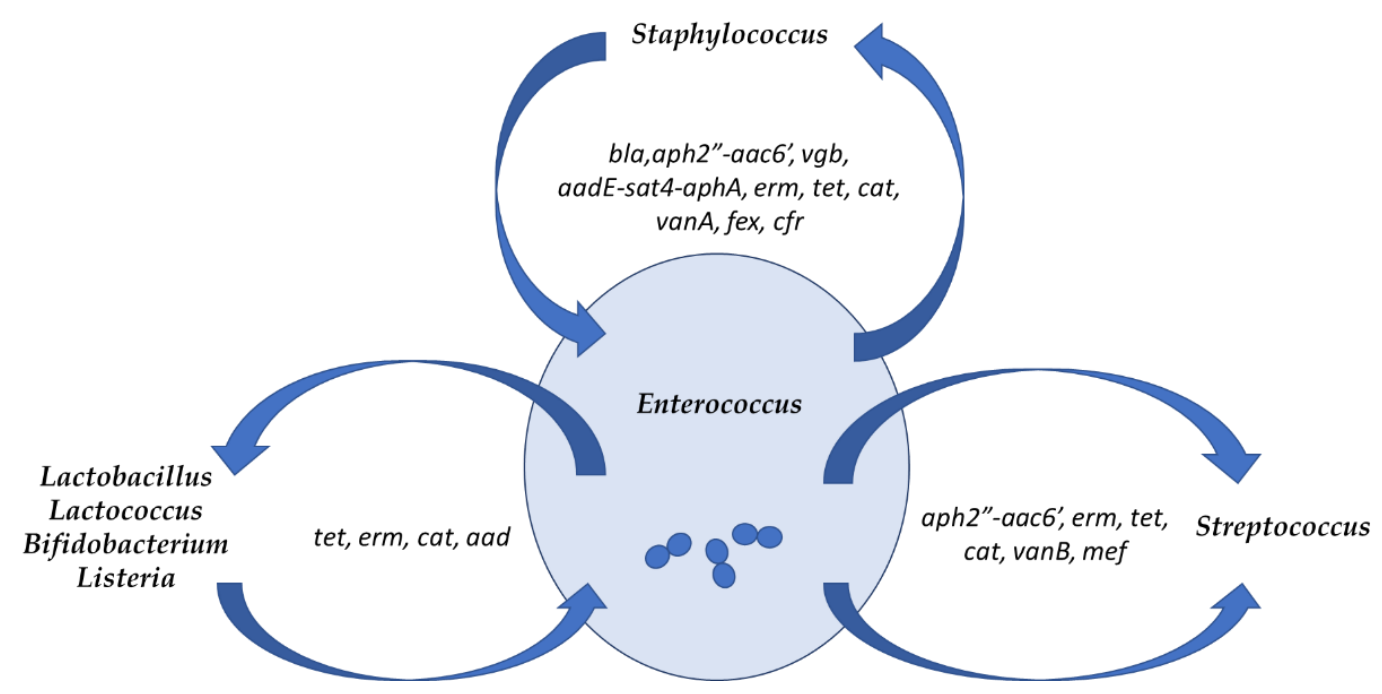

Figure 3. Shared genetic determinants of antibiotic resistance between enterococci and other bacteria that occupy the same habitats, with indication of the main genetic determinants of resistance shared; tet refers to either tet $K, L, M, O$, and/or $W$, and erm refers to erm A, B and/or C. (Data for this figure were obtained from Werner et al. [5]).

Enterococcus species are intrinsically resistant to cephalosporins, low levels of most other $\beta$-lactams, low levels of aminoglycosides, sulfonamides, clindamycin, quinupristin, and dalfopristin. In addition, E. casseliflavus and E. gallinarum possess intrinsic resistance to low levels of vancomycin [289]. Intrinsic resistance of enterococci to $\beta$-lactams (including cephalosporins) is due to expression of low-affinity penicillin-binding proteins (PBPs) that bind weakly to such antibiotics. Since enterococci do not synthesize folate, they are constitutively resistant to sulfonamides. Intrinsic resistance to lincosamides, streptogramin $\mathrm{A}$, and to the combination quinupristin-dalfopristin in E. faecalis is probably due to drug efflux, encoded in a chromosomally located gene (lsa). In E. faecalis, resistance to clinically achievable concentrations of aminoglycosides is intrinsic, and has been attributed to the low permeability of its cell wall to this type of molecules. Such a low-level resistance can be overcome by combining an aminoglycoside with a penicillin [296]. Resistances meanwhile acquired by Enterococcus include resistance to chloramphenicol, erythromycin, tetracycline, fluoroquinolones, glycopeptides and high levels of clindamycin, aminoglycosides, and $\beta$-lactams $[219,289]$.

Enterococci can increase their resistance to penicillins by acquiring the plasmid-borne bla genes that encode $\beta$-lactamases [289], or by mutations in PBP4 (E. faecalis) and PB5 (E. faecium) [219]. Production of $\beta$-lactamases is rare in enterococci and occurs mostly in E. faecalis [289].

The development of resistance to high levels of aminoglycosides in E. faecalis and E. faecium typically results from acquisition of mobile genetic elements encoding for antibioticmodifying enzymes. The major determinant of high-level resistance to this class of antibiotics is the bifunctional gene $a p h\left(2^{\prime \prime}\right)-I a-a a c\left(6^{\prime}\right)-I e$; it encodes for an antibiotic-modifying enzyme conferring resistance to all clinically relevant aminoglycosides, except streptomycin [289]. The enzyme involved in high-level resistance to streptomycin is usually encoded in the ant-6 gene [219].

From a medical perspective, dissemination of acquired resistance to glycopeptides, such as vancomycin and teicoplanin (by vancomycin-resistant enterococci, VRE) has been one of the most alarming developments, because of the importance of these bactericidal drugs when aminoglycoside/ $\beta$-lactam therapy is compromised by high-level aminoglycoside resistance. The target of vancomycin is the cell wall, where it interferes with establishment of the peptide crosslink, thus affecting stability of this bacterial structure. Nine operons conferring vancomycin resistance to enterococcal strains have been described so far. Four of them-van $A$, van $B, \operatorname{van} C$ and $\operatorname{van} M$ - encode replacement of the terminal D-alanine in the pentapeptide precursors with D-lactate, and confer resistance to both 
vancomycin and teicoplanin. The remaining operons (vanC, vanE, vanG, vanL, and vanN) lead to precursors containing a terminal D-serine. The strains that express said determinants display low-level resistance to vancomycin, but not to teicoplanin $[219,289,295]$. VRE genotypes vanA and vanB are the most prevalent in Europe, and VanA-type E. faecium is the most problematic for humans. Unlike what happens with E. faecium, both ampicillin resistance and vancomycin resistance are seldom found in E. faecalis [5].

Despite the profusion of studies on antibiotic resistance and its genetic determinants of clinical enterococci, few studies are available that focus on enterococcal species carried by traditional cheeses [44,152,166,179,193,273,297]. As shown in Table 2, E. faecalis isolates were proven to carry tetracycline-resistance determinants [44,179,193,273]. Both efflux protein (tet $K$, tet $L$ ) and ribosomal determinants (tet $M$, tet $S$ ) were found in these studies [44,130,193,273]. The genetic determinant for chloramphenicol resistant cat (which encodes for a chloramphenicol acetyltransferase) was also present in E. faecalis isolates from traditional cheeses [44,273]. Other genetic determinants detected were aadE (encoding for aminoglycoside 6-adenyltransferase involved in streptomycin resistance) [273], aph3' (an aminoglycoside phosphotransferase), and ermB (which encodes for a ribosomal protection protein involved in resistance to erythromycin) [44]. Vancomycin resistance determinants (vanA) were reported only in a single study [142], and just in two strains. E. faecium carrying genetic determinants of antibiotic resistance were rare $[179,273]$, with detection of tet $M$ in only one strain [273]. In E. italicus, only the tetS (which encodes for a ribosomal protection protein) and tet $K$ tetracycline-resistance determinants were found [193,297]. No genetic determinants of resistance were recorded for the E. gilvus strains studied [179].

Table 2. Antibiotic-resistance determinants and phenotypes reported for enterococcal strains from traditional cheeses.

\begin{tabular}{|c|c|c|c|}
\hline Enterococcal Species & $\begin{array}{c}\text { Genetic Determinants of } \\
\text { Resistance }\end{array}$ & Phenotypic Resistance to ${ }^{1}$ & Reference(s) \\
\hline E. durans & Not tested & ERY; CIP; PEN; TET; CHL & [102] \\
\hline E. faecalis & $\begin{array}{c}\text { tetK,L,M,S; aad } ; \text {; aph } 3^{\prime} ; \text { cat; } \\
\text { erm; vanA }\end{array}$ & $\begin{array}{l}\text { GENT; STR; KAN; NEO; CFT; } \\
\text { CFO; PEN; OXA; TET; MYN; } \\
\text { ERY; VAN; CHL; Q-D; SxT }\end{array}$ & {$[44,102,152,166,179,273]$} \\
\hline E. faecium & tetM & ERY; CIP; LEV; NOR; NIT & {$[179,273,298]$} \\
\hline E. gilvus & None detected & None detected & [179] \\
\hline E. italicus & tet $K, S$ & RIF; TET; TRI & {$[193,297]$} \\
\hline
\end{tabular}

Phenotypic resistance to aminoglycosides (low level), cephalosporins, penicillins, tetracyclines, trimethoprim, and sulfamethoxazole-trimethoprim was detected in E. faecalis isolates from cheese (Table 2). Resistance to these antibiotics is considered intrinsic in enterococci [289]. On the other hand, resistance to chloramphenicol, erythromycin, glycopeptides, quinupristin-dalfopristin, and tetracyclines is acquired. Among these, chloramphenicol and vancomycin are part of the World Health Organization (WHO) Model List of Essential Medicines [299], so preventing dissemination of resistance to these chemotherapeutic agents is important. Detection of phenotypic resistance to chloramphenicol and vancomycin is in line with presence of the corresponding genetic determinants shown in Table 2; and may raise concerns on the possibility of dissemination of resistance to these important antibiotics, even though resistance to vancomycin was infrequent [152]. Resistance to tetracycline also agrees with the wide dispersion of its genetic determinants among E. faecalis from traditional cheeses (Table 2); presence of multi-resistant strains (i.e., resistant to more than 3 antibiotics) in some studies is also noteworthy $[44,152,179,298]$. 
Regarding E. durans and E. faecium isolates, resistance to penicillin, erythromycin, tetracycline, levofloxacin, norfloxacin, ciprofloxacin, chloramphenicol, and nitrofurantoin was reported (Table 2). Resistance to the latter three is of concern, for not being intrinsic in enterococci, and they are regarded as essential antibiotics for humankind [299,300]. Despite the presence of tet $M$, tetracycline resistance was not reported in E. faecium as per these studies. Resistance against tetracycline in E. italicus was, however, consistent with presence of genetic determinants for drug efflux and ribosomal protection. Furthermore, all $E$. italicus strains were resistant to rifampicin and trimethoprim in one of the studies summarized in Table 2, so the authors claimed that this could be a characteristic trait of this species [193].

The number of available studies that analyzed in depth the antibiotic resistance and the enterococcal resistome in artisanal cheeses is low. Therefore, existing data cannot backup a thorough analysis of the risks associated with presence of antibiotic-resistant strains and transmissible genetic determinants of resistance.

However, presence of transmissible genetic determinants of resistance to clinically relevant antibiotics, such as aminoglycosides and vancomycin; the range of phenotypic resistance in E. faecalis strains; and presence of multi-resistant enterococci all raise concerns. Research on this issue is urgent, not only to help manage the spread of antibiotic resistance, but also to better document the safety status of strains that, due to their technological properties and probiotic potential, could provide a tool for quality improvement and innovation. Although these strains are part of the microbiota of cheeses that have a centurylong history of safe consumption, the circumstances have changed in the latest 80 years, since discovery of antibiotics and their introduction into clinical practice has raised a new selective pressure that is likely to shape enterococcal evolution in ways that may eventually impact human health.

\section{Conclusions}

Enterococci are an important part of the microbiota in many traditional cheeses, and their metabolic activities contribute to the unique sensorial properties associated with each type of cheese. Since they do not behave as strong acidifiers, they are not an ideal choice for starters, yet they may offer a promise toward development of cheese adjunct/protective cultures. Enterococci in cheese can impact the health of its consumers in many favorable ways, thus making them an interesting source of (potentially) probiotic strains. Enterococci are not highly virulent; and there are no reports of enterococcal infections linked to cheese consumption. Nevertheless, cheese enterococcal strains may harbor a few genetic determinants of virulence and antibiotic resistance, often located in mobile genetic elements. Enterococci have been touted as "gene traffickers", and can accordingly obtain and disseminate virulence and antibiotic virulence genes in the GIT of their hosts and in the environment. In this sense, they have the potential to constitute a health threat that urges some form of mitigation. However, knowledge of enterococci in artisanal cheeses is relatively scarce. By making use of the increasingly accessible highthroughput, culture-independent technologies in conjunction with classical bacteriology techniques, one should further investigate enterococcal diversity and population dynamics in these cheeses. A better understanding of their influence upon human health is a must, not only to minimize the risks associated with their ability to disseminate virulence and antibiotic-resistance genes, but also to permit a better exploitation of their potential as adjunct, protective, and probiotic cultures.

Author Contributions: Conceptualization, M.d.L.E.D. and F.X.M.; investigation, S.P.A.C., B.S., and P.P.; resources, F.X.M. and M.d.L.E.D.; data curation, S.P.A.C. and B.S.; writing-original draft preparation, S.P.A.C., B.S., P.P.; writing-review and editing, M.d.L.E.D. and F.X.M.; supervision, M.d.L.E.D. and F.X.M. All authors have read and agreed to the published version of the manuscript.

Funding: This work was financially supported by: PROMETHEUS-PTDC/BAA-AGR/29284/2017POCI-01-0145-FEDER-029284, funded by FEDER funds through COMPETE2020-Programa Opera- 
cional Competitividade e Internacionalização (POCI) and by national funds (PIDDAC) through FCT/MCTES; and Base Funding-UIDB/00511/2020 of the Laboratory for Process Engineering, Environment, Biotechnology and Energy-LEPABE-funded by national funds through the FCT/MCTES (PIDDAC). Author S.P.A.C. was funded by Regional Fund for Science and Technology, Portugal (grant M.3.2.DOCPROF/F/044/2020).

Conflicts of Interest: The authors declare no conflict of interest.

\section{References}

1. Casey, M.G.; Häni, J.-P.; Gruskovnjak, J.; Schaeren, W.; Wechsler, D. Characterisation of the non-starter lactic acid bacteria (NSLAB) of Gruyère PDO cheese. Lait 2006, 86, 407-414. [CrossRef]

2. Fox, P.F.; Cogan, T.M.; Guinee, T.P. Chapter 52. Factors That Affect the Quality of Cheese. In Cheese: Chemistry, Physics and Microbiology, 4th ed.; McSweeney, P.L.H., Fox, P.F., Cotter, P.D., Everett, D.W., Eds.; Elsevier: Amsterdam, The Netherlands, 2017; pp. 617-641.

3. Franz, C.M.A.P.; Van Belkum, M.J.; Holzapfel, W.H.; Abriouel, H.; Gálvez, A. Diversity of enterococcal bacteriocins and their grouping in a new classification scheme. FEMS Microbiol. Rev. 2007, 31, 293-310. [CrossRef]

4. Lebreton, F.; Willems, R.J.L.; Gilmore, M. Enterococcus diversity, origins in nature, and gut colonization. In Enterococci: From Commensals to Leading Causes of Drug Resistant Infection; Gilmore, M.S., Clewell, D.B., Ike, Y., Shankar, N., Eds.; Massachusetts Eye and Ear Infirmary: Boston, MA, USA, 2014; pp. 5-63.

5. Werner, G.; Coque, T.M.; Franz, C.M.; Grohmann, E.; Hegstad, K.; Jensen, L.; van Schaik, W.; Weaver, K. Antibiotic resistant enterococci-tales of a drug resistance gene trafficker. Int. J. Med. Microbiol. 2013, 303, 360-379. [CrossRef]

6. Arias, C.; Murray, B. The rise of the Enterococcus: Beyond vancomycin resistance. Nat. Rev. Microbiol. 2012, 10, 266-278. [CrossRef]

7. Graham, K.; Stack, H.; Rea, R. Safety, beneficial and technological properties of enterococci for use in functional food applications-a review. Crit. Rev. Food Sci. Nutr. 2020, 60, 3836-3861. [CrossRef] [PubMed]

8. Hanchi, H.; Mottawea, W.; Sebei, K.; Hammami, R. The genus Enterococcus: Between probiotic potential and safety concerns-an update. Front. Microbiol. 2018, 9, 1791. [CrossRef] [PubMed]

9. Billroth, A.W. Untersuchungen über die Vegetationsformen von Coccobacteria Septica; Georg Reimer: Berlin, Germany, 1874.

10. Rosenbach, F.J. Mikro-Organismen bei den Wund-Infections-Krankheiten des Menschen; Bergmann, J.F., Ed.; Verlag from J.F. Bergmann: Wiesbaden, Germany, 1884.

11. Thiercelin, E.; Jouhaud, L. Reproduction de l'entérocoque; taches centrales; granulations peripheriques et microblastes. Comptes Rendus Seances Soc. Biol. Paris 1903, 55, 686-688.

12. Andrews, F.W.; Horder, T.J. A study of streptococci pathogenic for man. Lancet 1906, 2, 708-713. [CrossRef]

13. Lancefield, R.C. A serological differentiation of human and other groups of hemolytic streptococci. J. Exp. Med. 1933, 57, 571-595. [CrossRef]

14. Sherman, J.M. The enterococci and related streptococci. J. Bacteriol 1937, 35, 81-93. [CrossRef]

15. Schleifer, K.H.; Kilpper-Bälz, R. Transfer of Streptococcus faecalis and Streptococcus faecium to the genus Enterococcus nom. rev. as Enterococcus faecalis comb. nov. and Enterococcus faecium comb. nov. Int. J. Syst. Bacteriol. 1984, 34, 31-34.

16. DSMZ. LPSN-List of Prokaryotic Names with Standing in Nomenclature. 2020. Available online: https://lpsn.dsmz.de/ (accessed on 10 February 2021).

17. Lebreton, F.; Manson, A.L.; Saavedra, J.T.; Straub, T.J.; Earl, A.M.; Gilmore, M.S. Tracing the enterococci from Paleozoic origins to the hospital. Cell 2017, 169, 849-861. [CrossRef] [PubMed]

18. Mundt, J.O. Occurrence of enterococci in animals in a wild environment. J. Appl. Microbiol. 1963, 11, 136-140. [CrossRef]

19. Martin, J.D.; Mundt, J.O. Enterococci in insects. J. Appl. Microbiol. 1972, 24, 575-580. [CrossRef]

20. Silva, V.; Peixoto, F.; Igrejas, G.; Parelho, C.; Garcia, P.; Carvalho, I.; Sousa, M.; Pereira, J.E.; Rodrigues, A.; Poeta, P. First report on vanA-Enterococcus faecalis recovered from soils subjected to long-term livestock agricultural practices in Azores Archipelago. Int. J. Environ. Res. 2018, 12, 39-44. [CrossRef]

21. Ben Said, L.B.; Klibi, N.; Dziri, R.; Borgo, F.; Boubadous, A.; Ben Slama, K.; Torres, C. Prevalence, antimicrobial resistance and genetic lineages of Enterococcus spp. from vegetable food, soil and irrigation water in farm environments in Tunisia. J. Sci. Food Agric. 2016, 96, 1627-1633. [CrossRef]

22. Moore, D.F.; Guzman, J.A.; McGee, C. Species distribution and antimicrobial resistance of enterococci isolated from surface and ocean water. J. Appl. Microbiol. 2008, 105, 1017-1025. [CrossRef]

23. Müller, T.; Ulrich, A.; Ott, E.-M.; Müller, M. Identification of plant-associated enterococci. J. Appl. Microbiol. 2001, 91, 268-278. [CrossRef] [PubMed]

24. Gao, W.; Howden, B.P.; Stinear, T.P. Evolution of virulence in Enterococcus faecium, a hospital-adapted opportunistic pathogen. Curr. Opin. Microbiol. 2018, 41, 76-82. [CrossRef]

25. Ben Braiek, O.; Smaoui, S. Enterococci: Between Emerging Pathogens and Potential Probiotics. Biomed. Res. Int. 2019, 2019, 5938210. [CrossRef]

26. Novais, C.; Campos, J.; Freitas, A.R.; Barros, M.; Silveira, E.; Coque, T.M.; Antunes, P.; Peixe, L. Water supply and feed as sources of antimicrobial-resistant Enterococcus spp. in aquacultures of rainbow trout (Oncorhyncus mykiss), Portugal. Sci. Total Environ. 2018, 625, 1102-1112. [CrossRef] [PubMed] 
27. Channaiah, L.H.; Subramanyam, B.; Zurek, L. Molecular characterization of antibiotic resistant and potentially virulent enterococci isolated from swine farms and feed mills. J. Stored Prod. Res. 2018, 77, 189-196. [CrossRef]

28. Lleò, M.M.; Bonato, B.; Benedetti, D.; Canepari, P. Survival of enterococcal species in aquatic environments. FEMS Microbiol. Ecol. 2005, 54, 189-196. [CrossRef] [PubMed]

29. Zhong, Z.; Kwok, L.-Y.; Hou, Q.; Sun, Y.; Li, W.; Zhang, L.; Sun, Z. Comparative genomic analysis revealed great plasticity and environmental adaptation of the genomes of Enterococcus faecium. BMC Genom. 2019, 20, 60. [CrossRef]

30. Quigley, L.; O'Sullivan, O.; Stanton, C.; Beresford, T.P.; Ross, R.P.; Fitzgerald, G.F.; Cotter, P.D. The complex microbiota of raw milk. FEMS Microbiol. Rev. 2013, 37, 664-698. [CrossRef] [PubMed]

31. Perin, L.M.; Miranda, R.O.; Todorov, S.D.; Franco, B.D.G.; Nero, L.A. Virulence, antibiotic resistance and biogenic amines of bacteriocinogenic lactococci and enterococci isolated from goat milk. Int. J. Food Microbiol. 2014, 185, 121-126. [CrossRef]

32. Giraffa, G. Enterococci from foods. FEMS Microbiol. Rev. 2003, 26, 163-171. [CrossRef]

33. Garg, S.K.; Mital, B.K. Enterococci in milk and milk products. Crit. Rev. Microbiol. 1991, 18, 15-45. [CrossRef]

34. Gelsomino, R.; Vancanneyt, M.; Cogan, T.M.; Condon, S.; Swings, J. Source of enterococci in a farmhouse raw-milk cheese. Appl. Environ. Microbiol. 2002, 68, 3560-3565. [CrossRef]

35. Kakgli, D.M.; Vancanneyt, M.; Vandamme, P.; Hill, C.; Cogan, T.M. Contamination of milk by enterococci and coliforms from bovine faeces. J. Appl. Microbiol. 2007, 103, 1393-1405. [CrossRef]

36. Kakgli, D.M.; Vancanneyt, M.; Hill, C.; Vandamme, P.; Cogan, T.M. Enterococcus and Lactobacillus contamination of raw milk in a farm dairy environment. Int. J. Food Microbiol. 2007, 114, 243-251. [CrossRef]

37. Ortigosa, M.; Irigoyen, A.; Urdin, M.; García, S.; Ibañez, F.C.; Torre, P. Sources of enterococci in Idiazábal-type cheese. Int. J. Food Microbiol. 2008, 125, 146-152. [CrossRef]

38. Wu, X.; Hou, S.; Zhang, Q.; Ma, Y.; Zhang, Y.; Kan, W.; Zhao, X. Prevalence of virulence and resistance to antibiotics in pathogenic enterococci isolated from mastitic cows. J. Vet. Med. Sci. 2016, 78, 1663-1668. [CrossRef]

39. McAuley, C.M.; Britz, M.L.; Gobius, K.S.; Craven, H. Prevalence, seasonality, and growth of enterococci in raw and pasteurized milk in Victoria, Australia. J. Dairy Sci. 2015, 98, 8348-8358. [CrossRef]

40. Giraffa, G.; Carminati, D.; Neviani, E. Enterococci isolated from dairy products: A review of risks and potential technological use. J. Food Prot. 1997, 60, 732-738. [CrossRef]

41. McAuley, C.; Gobius, K.S.; Britz, M.L.; Craven, H.M. Heat resistance of thermoduric enterococci isolated from milk. Int. J. Food Microbiol. 2012, 154, 162-168. [CrossRef]

42. Martínez, S.; López, M.; Bernardo, A. Thermal inactivation of Enterococcus faecium: Effect of growth temperature and physiological state of microbial cells. Lett. Appl. Microbiol. 2003, 37, 475-481. [CrossRef]

43. Didienne, R.; Defargues, C.; Callon, C.; Meylheuc, T.; Hulin, S.; Montel, M.-C. Characteristics of microbial biofilm on wooden vats ('gerles') in PDO Salers cheese. Int. J. Food Microbiol. 2012, 156, 91-101. [CrossRef] [PubMed]

44. Jamet, E.; Akary, E.; Poisson, M.-A.; Chamba, J.-F.; Bertrand, X.; Serror, P. Prevalence and characterization of antibiotic resistant Enterococcus faecalis in French cheeses. Food Microbiol. 2012, 31, 191-198. [CrossRef] [PubMed]

45. Bouymajane, A.; Filali, F.R.; Oulghazi, S.; Ed-dra, A.; Benhallam, F.; El Allaoui, A.; Anissi, K.; Ouhmidou, B.; Moumni, M. Occurrence, molecular and antimicrobial resistance of Enterococcus spp. isolated from raw cow's milk trade by street trading in Meknes city, Morocco. Germs 2018, 9, 77-84. [CrossRef] [PubMed]

46. Garroni, E.; Doulgeraki, A.I.; Pavli, F.; Spiteri, D.; Valdramidis, V.P. Characterization of indigenous lactic acid bacteria in cow milk of the Maltese Islands: A geographical and seasonal assessment. Microorganisms 2020, 8, 812. [CrossRef]

47. Montel, M.-C.; Buchin, S.; Mallet, A.; Delbes-Paus, C.; Vuitton, D.A.; Desmasures, N.; Berthier, F. Traditional cheeses: Rich and diverse microbiota with associated benefits. Int. J. Food Microbiol. 2014, 177, 136-154. [CrossRef] [PubMed]

48. Giannino, M.L.; Marzotto, M.; Dellaglio, F.; Feligni, M. Study of microbial diversity in raw milk and fresh curd used for Fontina cheese production by culture-independent methods. Int. J. Food Microbiol. 2009, 130, 188-195. [CrossRef] [PubMed]

49. Masoud, W.; Vogensen, F.K.; Lillevang, S.; Al-Soud, W.A.; Sørensen, S.J.; Jakobsen, M. The fate of indigenous microbiota, starter cultures, Escherichia coli, Listeria innocua and Staphylococcus aureus in Danish raw milk and cheeses determined by pyrosequencing and quantitative real time (qRT)-PCR. Int. J. Food Microbiol. 2012, 153, 192-202. [CrossRef] [PubMed]

50. Von Neubeck, M.; Baur, C.; Krewinkel, M.; Stoeckel, M.; Kranz, B.; Stressler, T.; Fischer, L.; Hinrichs, J.; Scherer, S.; Wenning, M. Biodiversity of refrigerated raw milk microbiota and their enzymatic spoilage potential. Int. J. Food Microbiol. 2015, $211,57-65$. [CrossRef] [PubMed]

51. Alves, P.I.; Martins, M.P.; Semedo, T.; Marques, J.J.F.; Tenreiro, R.; Crespo, M.T.B. Comparison of phenotypic and genotypic taxonomic methods for the identification of dairy enterococci. Antonie van Leeuwenhoek 2003, 85, 237-252. [CrossRef] [PubMed]

52. Citak, S.; Yucel, N.; Mendi, A. Antibiotic resistance of enterococcal isolates in raw milk. J. Food Process. Preserv. 2015, $29,183-195$. [CrossRef]

53. Fricker, M.; Skånseng, B.; Rudi, K.; Stessl, B.; Ehling-Schulz, M. Shift from farm to dairy tank milk microbiota revealed by a polyphasic approach is independent from geographical origin. Int. J. Food Microbiol. 2011, 145, S24-S30. [CrossRef]

54. Jiménez, E.; Ladero, V.; Chico, I.; Maldonado-Barragán, A.; López, M.; Martín, V.; Fernández, L.; Fernández, M.; Álvarez, M.A.; Torres, C.; et al. Antibiotic resistance, virulence determinants and production of biogenic amines among enterococci from ovine, feline, canine, porcine and human milk. BMC Microbiol. 2013, 13, 288. [CrossRef] 
55. Garnica, M.L.; Sáez-Nieto, J.A.; González, R.; Santos, J.A.; Gonzalo, C. Diversity of gram-positive catalase-negative cocci in sheep bulk tank milk by comparative $16 \mathrm{~S}$ rDNA sequence analysis. Int. Dairy J. 2014, 34, 142-145. [CrossRef]

56. Ariznabarreta, A.; Gonzalo, C.; San Primitivo, F. Microbiological quality and somatic cell count of ewe milk with special reference to staphylococci. J. Dairy Sci. 2002, 85, 1370-1375. [CrossRef]

57. Ruiz, P.; Pérez-Martín, F.; Seseña, S.; Palop, M.L. Seasonal diversity and safety evaluation of enterococci population from goat milk in a farm. Dairy Sci. Technol. 2016, 96, 359-375. [CrossRef]

58. Cocolin, L.; Foschino, R.; Comi, G.; Fortina, M.G. Description of the bacteriocins produced by two strains of Enterococcus faecium isolated from Italian goat milk. Food Microbiol. 2007, 24, 752-758. [CrossRef] [PubMed]

59. Perin, L.M.; Todorov, S.D.; Nero, L.A. Investigation of genes involved in nisin production in Enterococcus spp. strains isolated from raw goat milk. Antonie van Leeuwenhoek 2016, 109, 1271-1280. [CrossRef]

60. Perin, L.M.; Nero, L.A. Antagonistic lactic acid bacteria isolated from goat milk and identification of a novel nisin variant Lactococcus lactis. BMC Microbiol. 2014, 14, 36. [CrossRef] [PubMed]

61. Júnior, W.L.G.A.; Ferrari, I.S.; Souza, J.V.; Silva, C.D.A.; Costa, M.M.; Dias, F.S. Characterization and evaluation of lactic acid bacteria isolated from goat milk. Food Control 2015, 53, 96-103. [CrossRef]

62. Sarkar, S.L.; Hossain, M.I.; Monika, S.A.; Sanyal, S.K.; Roy, P.C.; Hossain, M.A.; Jahid, I.K. Probiotic potential of Pediococcus acidilactici and Enterococcus faecium isolated from indigenous yogurt and raw goat milk. Microbiol. Biotechnol. Lett. 2020, 48, 276-286. [CrossRef]

63. Achemchem, F.; Cebrián, R.; Abrini, J.; Martínez-Bueno, M.; Valdivia, E.; Maqueda, M. Antimicrobial characterization and safety aspects of the bacteriocinogenic Enterococcus hirae F420 isolated from Moroccan raw goat milk. Can. J. Microbiol. 2012, 58, 596-604. [CrossRef]

64. Callon, C.; Duthoit, F.; Delbès, C.; Ferrand, M.; Le Frileux, Y.; De Crémoux, R.; Montel, M.-C. Stability of microbial communities in goat milk during a lactation year: Molecular approaches. Syst. Appl. Microbiol. 2007, 30, 547-560. [CrossRef] [PubMed]

65. Perin, L.M.; Pereira, J.G.; Bersot, L.S.; Nero, L.A. The microbiology of raw milk. In Raw Milk: Balance between Hazards and Benefits; Nero, L.A., Carvalho, A.F., Eds.; Academic Press: Chennai, India, 2019; pp. 45-64.

66. Franciosi, E.; Settanni, L.; Cavazza, A.; Poznanski, E. Biodiversity and technological potential of wild lactic acid bacteria from raw cow's milk. Int. Dairy J. 2009, 19, 3-11. [CrossRef]

67. Hantsis-Zacharov, E.; Halpern, M. Culturable psychrotrophic bacterial communities in raw milk and their proteolytic and lipolytic traits. Appl. Environ. Microbiol. 2007, 73, 7162-7168. [CrossRef]

68. Banwo, K.; Sanni, A.; Tan, H. Technological properties and probiotic potential of Enterococcus faecium strains isolated from cow milk. J. Appl. Microbiol. 2012, 114, 229-241. [CrossRef]

69. Elkenany, R.M.; Elsayed, M.M.; Eltaysh, R.A.; Zakaria, A.I.; El-Baz, A.H. In vitro probiotic characteristics of Enterococcus species isolated from raw cow milk. Int. J. Probiotics Prebiotics 2018, 13, 117.

70. Bouton, Y.; Guyot, P.; Grappin, R. Preliminary characterization of microflora of Comté cheese. J. Appl. Microbiol. 1998, 85, $123-131$. [CrossRef]

71. Pappa, E.C.; Kondyli, E.; Samelis, J. Microbiological and biochemical characteristics of Kashkaval cheese produced using pasteurized or raw milk. Int. Dairy J. 2019, 89, 60-67. [CrossRef]

72. Dal Bello, B.; Rantsiou, K.; Bellio, A.; Zeppa, G.; Ambrosoli, R.; Civera, T.; Cocolin, L. Microbial ecology of artisanal products from North West of Italy and antimicrobial activity of the autochthonous populations. LWT Food Sci. Technol. 2010, 43, 1151-1159. [CrossRef]

73. Morandi, S.; Brasca, M.; Lodi, R. Technological, phenotypic and genotypic charaterisation of wild lactic acid bacteria involved in the production of Bitto PDO Italian cheese. Dairy Sci. Technol. 2011, 91, 341-359. [CrossRef]

74. Calasso, M.; Ercolini, D.; Mancini, L.; Stellato, G.; Minervini, F.; Di Cagno, R.; De Angelis, M.; Gobetti, M. Relationships among house, rind, and core microbiotas during manufacture of traditional Italian cheeses at the same dairy plant. Food Microbiol. 2016, 54, 115-126. [CrossRef]

75. Di Grigoli, A.; Francesca, N.; Gaglio, R.; Guarrasi, V.; Moschetti, M.; Scatassa, M.L.; Settanni, L.; Bonanno, A. The influence of the wooden equipment employed for cheese manufacture on the characteristics of a traditional stretched cheese during ripening. Food Microbiol. 2015, 81-91. [CrossRef] [PubMed]

76. Casalta, E.; Sorba, J.-M.; Aigle, M.; Ogier, J.-C. Diversity and dynamics of the microbial community during the manufacture of Calenzana, an artisanal Corsican cheese. Int. J. Food Microbiol. 2009, 133, 243-251. [CrossRef]

77. Pisano, M.B.; Fadda, M.E.; Deplano, M.; Corda, A.; Cosentino, S. Microbiological and chemical characterization of Fiore Sardo, a traditional Sardinian cheese made from ewe's milk. Int. J. Dairy Technol. 2006, 59, 171-179. [CrossRef]

78. Carraro, L.; Maifreni, M.; Bartolomeoli, I.; Martino, M.E.; Novelli, E.; Frigo, F.; Marino, M.; Cardazzo, B. Comparison of culturedependent and -independent methods for bacterial community monitoring during Montasio cheese manufacturing. Res. Microbiol. 2011, 162, 231-239. [CrossRef]

79. Marino, M.; Maifreni, M.; Rondinini, G. Microbiological characterization of artisanal Montasio cheese: Analysis of its indigenous lactic acid bacteria. FEMS Microbiol. Lett 2003, 133-140. [CrossRef]

80. Franciosi, E.; Carafa, I.; Nardin, T.; Schiavon, S.; Poznanski, E.; Cavazza, A.; Larcher, R.; Tuohy, K.M. Biodiversity and $\gamma-$ aminobutyric acid production by lactic acid bacteria isolated from traditional alpine raw cow's milk cheeses. BioMed Res. Int. 2014, 2015, 625740. [CrossRef] 
81. Poznanski, E.; Cavazza, A.; Cappa, F.; Cocconcelli, P.S. Indigenous raw milk microbiota influences the bacterial development in traditional cheese from an alpine natural park. Int. J. Food Microbiol. 2004, 92, 141-151. [CrossRef]

82. Randazzo, C.; Vaughan, E.E.; Caggia, C. Artisanal and experimental Pecorino Siciliano cheese: Microbial dynamics during manufacture assessed by culturing and PCR-DGGE analyses. Int. J. Food Microbiol. 2006, 109, 1-8. [CrossRef] [PubMed]

83. Aponte, M.; Fusco, V.; Andolfi, R.; Coppola, S. Lactic acid bacteria occurring during manufacture and ripening of Provolone del Monaco cheese: Detection by different analytical approaches. Int. Dairy J. 2008, 18, 403-413. [CrossRef]

84. Dolci, P.; Alessandria, V.; Zeppa, G.; Rantsiou, K.; Cocolin, L. Microbiological characterization of artisanal Raschera PDO cheese: Analysis of its indigenous lactic acid bacteria. Food Microbiol. 2008, 25, 392-399. [CrossRef] [PubMed]

85. Suzzi, G.; Caruso, M.; Gardini, F.; Lombardi, A.; Vannini, L.; Guerzoni, M.E.; Andrighetto, C.; Lanorte, M.T. A survey of the enterococci isolated from an artisanal Italian goat's cheese (semicotto caprino). J. Appl. Microbiol. 2000, 89, 267-274. [CrossRef] [PubMed]

86. Colombo, E.; Franzetti, L.; Frusca, M.; Scarpellini, M. Phenotypic and genotypic characterization of lactic acid bacteria isolated from artisanal Italian goat cheese. J. Food Prot. 2010, 73, 657-662. [CrossRef] [PubMed]

87. Gaglio, R.; Cruciata, M.; Scatassa, M.L.; Tolone, M.; Mancuso, I.; Cardamone, C.; Corona, O.; Todaro, M.; Settanni, L. Influence of the early bacterial biofilms developed on vats made with seven wood types on PDO Vastedda della valle del Belice cheese characteristics. Int. J. Food Microbiol. 2019, 291, 91-103. [CrossRef]

88. Tavaria, F.; Malcata, F.X. Microbiological characterization of Serra da Estrela cheese throughout its Appelation d'Origine Protégée Region. J. Food Prot. 1998, 61, 601-607. [CrossRef] [PubMed]

89. Macedo, A.C.; Tavares, T.G.; Malcata, F.X. Influence of native lactic acid bacteria on the microbiological, biochemical and sensory profiles of Serra da Estrela cheese. Food Microbiol. 2004, 21, 233-240. [CrossRef]

90. Pinho, O.; Pintado, A.I.E.; Gomes, A.M.P.; Pintado, M.E.; Malcata, F.X.; Ferreira, I.M.P.L.V.O. Interrelationships among microbiological, physicochemical, and biochemical properties of Terrincho cheese, with emphasis on biogenic amines. J. Food Prot. 2004, 67, 2779-2785. [CrossRef]

91. Alegría, A.; Álvarez-Martín, P.; Sacristán, N.; Fernández, E.; Delgado, S.; Mayo, B. Diversity and evolution of the microbial populations during manufacture and ripening of Casín, a traditional Spanish, starter-free cheese made from cow's milk. Int. J. Food Microbiol. 2009, 136, 44-51. [CrossRef]

92. Martín-Platero, A.M.; Valdivia, E.; Maqueda, M.; Martín-Sánchez, I.; Martínez-Bueno, M. Polyphasic approach to bacterial dynamics during the ripening of Spanish farmhouse cheese, using culture-dependent and -independent methods. Appl. Environ. Microbiol. 2008, 74, 5662-5673. [CrossRef]

93. Picon, A.; Garde, S.; Ávila, M.; Nuñez, M. Microbiota dynamics and lactic acid bacteria biodiversity in raw goat milk cheeses. Int. Dairy J. 2016, 58, 14-22. [CrossRef]

94. Diezhandino, I.; Fernández, D.; González, L.; McSweeney, P.L.H.; Fresno, J.M. Microbiological, physico-chemical and proteolytic changes in a Spanish blue cheese during ripening (Valdeón cheese). Food Chem. 2015, 168, 134-141. [CrossRef] [PubMed]

95. Dráb, V.; Kavková, M.; Markvartová, M.; Hanáková, J.; Roubal, P. Microbial diversity of Livanjski cheese with the emphasis on lactic acid bacteria based on culture-dependent and sequencing method. Int. J. Dairy Technol. 2020, 73, 202-214. [CrossRef]

96. De Freitas, I.; Pinon, N.; Thierry, A.; Lopez, C.; Maubois, J.-L.; Lortal, S. In depth dynamic characterization of French PDO Cantal cheese made from raw milk. Lait 2007, 87, 97-117. [CrossRef]

97. Asteri, I.-A.; Robertson, N.; Kagkli, D.-M.; Andrewes, P.; Nychas, G.; Coolbear, T.; Holland, R.; Crow, V.; Tsakalidou, E. Technological and flavour potential of cultures isolated from traditional Greek cheeses-A pool of novel species and starters. Int. Dairy J. 2009, 19, 595-604. [CrossRef]

98. Samelis, J.; Kakouri, A. Major technological differences between and industrial-type and five artisan-type Greek PDO Galotyri market cheeses as revealed by great variations in their lactic acid microbiota. AIMS Agric. Food 2019, 4, 685-710. [CrossRef]

99. Giannou, E.; Lianou, A.; Kakouri, A.; Kallimanis, A.; Drainas, C.; Samelis, J. Identification and biopreservation potential of Enterococcus spp. isolated from fully ripened Graviera, a traditional hard Greek cheese. Ital. J. Food Sci. 2009, 21, 135-148.

100. Vandera, E.; Kakouri, A.; Koukkou, A.-I.; Samelis, J. Major ecological shifts within the dominant nonstarter lactic acid bacteria in mature Greek Graviera cheese as affected by the starter culture type. Int. J. Food Microbiol. 2019, 290, 15-26. [CrossRef] [PubMed]

101. Zoumpopoulou, G.; Papadimitriou, K.; Alexandraki, V.; Mavrogonatou, E.; Alexopoulou, K.; Anastasiou, R.; Gerogalaki, M.; Kletsas, D.; Tsakalidou, E.; Giaouris, E. The microbiota of Kalathaki and Melichloro Greek artisanal cheeses comprises functional lactic acid bacteria. LWT Food Sci. Technol. 2020, 130, 109570. [CrossRef]

102. Serio, A.; Paparella, A.; Chaves-López, C.; Corsetti, A.; Suzzi, G. Enterococcus populations in Pecorino Abruzzese cheese: Biodiversity and safety aspects. J. Food Prot. 2007, 70, 1561-1568. [CrossRef] [PubMed]

103. Campolo, O.; Romeo, F.V.; Attinà, A.; Zappalà, L.; Palmeri, V. Hygienic and physicochemical quality characterization of artisanal and industrial Pecorino Calabrese cheese. Int. J. Dairy Technol. 2013, 66, 595-603. [CrossRef]

104. Bonomo, M.G.; Salzano, G. Microbial diversity and dynamics of Pecorino di Filiano PDO, a traditional cheese of Basilicata region (Southern Italy). Int. J. Dairy Technol. 2012, 65, 1-11. [CrossRef]

105. Mormile, A.; Barile, M.; Mercogliano, R.; Johansson, P.; Björkroth, K.J.; Aponte, M.; Murru, N. Dynamics of lactic acid bacteria in "Pecorino di Tramonti"-a ewe's milk cheese-with particular emphasis on enterococci: A preliminary study. Ann. Microbiol. 2016, 66, 179-185. [CrossRef] 
106. Todaro, M.; Francesca, N.; Reale, S.; Moschetti, G.; Vitale, F.; Settanni, L. Effect of different salting technologies on the chemical and microbiological characteristics of PDO Pecorino Siciliano cheese. Eur. Food Res. Technol. 2011, 233, 931-940. [CrossRef]

107. Todaro, M.; Palmeri, M.; Settanni, L.; Scatassa, M.L. Effect of refrigerated storage on microbiological, chemical and sensory characteristics of a ewe's raw milk stretched cheese. Food Packag. Shelf Life 2017, 11, 67-73. [CrossRef]

108. Casalta, E.; Zennaro, R. Effect of specific starters on microbiological, biochemical and sensory characteristics of Venaco, a Corsican soft cheese. Sci. Aliment. 1997, 17, 79-94.

109. Freitas, A.C.; Malcata, F.X. Influence of milk type, coagulant, salting procedure and ripening time on the final characteristics of Picante cheese. Int. Dairy J. 1996, 6, 109-1116. [CrossRef]

110. Freitas, A.C.; Malcata, F.X. Technological optimization of Picante cheese using microbiological, chemical and physical criteria. J. Food Eng. 1999, 41, 163-175. [CrossRef]

111. Gonçalves, M.T.P.; Benito, M.J.; Córdoba, M.G.; Egas, C.; Merchán, A.V.; Galván, A.I.; Ruiz-Moyano, S. Bacterial communities in Serpa cheese by culture dependent techniques, $16 \mathrm{~S}$ rRNA gene senquencing and high-throughput sequencing analysis. J. Food Sci. 2018, 83, 1333-1341. [CrossRef] [PubMed]

112. Dahl, S.; Tavaria, F.K.; Malcata, F.X. Relationships between flavour and microbiological profiles in Serra da Estrela cheese throughout ripening. Int. Dairy J. 2000, 10, 255-262. [CrossRef]

113. Tavaria, F.K.; Malcata, F.X. On the microbiology of Serra da Estrela cheese: Geographical and chronological considerations. Food Microbiol. 2000, 17, 293-304. [CrossRef]

114. Macedo, A.C.; Malcata, F.X. Technological optimization of the manufacture of Serra cheese. J. Food Eng. 1997, 31, 433-447. [CrossRef]

115. Pintado, A.I.; Pinho, O.; Ferreira, I.M.; Pintado, M.M.; Gomes, A.M.; Malcata, F.X. Microbiological, biochemical and biogenic amine profiles of Terrincho cheese manufactured in several dairy farms. Int. Dairy J. 2008, 18, 631-640. [CrossRef]

116. Muruzović, M.Ž.; Mladenović, K.G.; Žugić-Petrović, T.D.; Čomić, L.R. Characterization of lactic acid bacteria isolated from traditionally made Serbian Cheese and evaluation of their antagonistic potential against Enterobacteriaceae. J. Food Process. Preserv. 2018, 42, e13577. [CrossRef]

117. Abriouel, H.; Martín-Platero, A.; Maqueda, M.; Valdivia, E.; Martínez-Bueno, M. Biodiversity of the microbial community in a Spanish farmhouse cheese as revealed by culture-dependent and culture-independent methods. Int. J. Food Microbiol. 2008, 127, 200-208. [CrossRef]

118. Martín-Platero, A.M.; Maqueda, M.; Valdivia, E.; Purswani, J.; Martínez-Bueno, M. Polyphasic study of microbial communities of two Spanish farmhouse goats' milk cheeses from Sierra de Aracena. Food Microbiol. 2009, 26, 294-304. [CrossRef]

119. Ordiales, E.; Martín, A.; Benito, M.J.; Hernández, A.; Ruiz-Moyano, S.; Córdoba, M.G. Role of the microbial population on the flavor of the soft-bodied cheese Torta del Casar. J. Dairy Sci. 2013, 96, 5477-5486. [CrossRef]

120. Yunita, D.; Dodd, C.E.R. Microbial community dynamics of a blue-veined raw milk cheese from the United Kingdom. J. Dairy Sci. 2017, 101, 4923-4935. [CrossRef]

121. Van Hoorde, K.; Verstraete, T.; Vandamme, P.; Huys, G. Diversity of lactic acid bacteria in two Flemish artisan raw milk Gouda-type cheeses. Food Microbiol. 2008, 25, 929-935. [CrossRef]

122. Delgado, S.; Mayo, B. Phenotypic and genetic diversity of Lactococcus lactis and Enterococcus spp. strains isolated from Northern Spain starter-free farmhouse cheeses. Int. J. Food Microbiol. 2004, 90, 309-319. [CrossRef]

123. Colombo, F.; Borgo, F.; Fortina, M.G. Genotypic characterization of non-starter lactic acid bacteria involved in the ripening of artisanal Bitto PDO cheese. J. Basic Microbiol. 2009, 49, 521-530. [CrossRef] [PubMed]

124. Jurkovic, D.; Križková, L.; Sojka, M.; Belicová, A.; Dušinský, R.; Krajčovič, J.; Snauwaert, C.; Naser, S.; Vandamme, P.; Vancanneyt, M. Molecular identification and diversity of enterococci isolated from Slovak Bryndza cheese. J. Gen. Appl. Microbiol. 2006, 52, 329-337. [CrossRef] [PubMed]

125. Jurkovic, D.; Križková, L.; Sojka, M.; Takáčova, M.; Dušinský, R.; Krajčovič, J.; Vandamme, P.; Vancanneyt, M. Genetic diversity of Enterococcus faecium isolated from Bryndza cheese. Int. J. Food Microbiol. 2007, 116, 82-87. [CrossRef] [PubMed]

126. Pangallo, D.; Šaková, N.; Koreňová, J.; Puškárová, A.; Kraková, L.; Valík, L.; Kuchta, T. Microbial diversity and dynamics during the production of May bryndza cheese. Int J. Food Microbiol. 2014, 170, 38-43. [CrossRef] [PubMed]

127. Guarrasi, V.; Sannino, C.; Moschetti, M.; Bonanno, A.; Di Grigoli, A.; Settani, L. The individual contribution of starter and non-starter lactic acid bacteria to the volatile organic compound composition of Caciocavallo Palermitano cheese. Int. J. Food Microbiol. 2017, 259, 35-42. [CrossRef]

128. Aquilanti, L.; Dell'Aquila, L.; Zannini, E.; Zocchetti, A.; Clementi, F. Resident lactic acid bacteria in raw milk Canestrato Pugliese cheese. Lett Appl. Microbiol. 2006, 43, 161-167. [CrossRef] [PubMed]

129. Fontana, C.; Cappa, F.; Rebecchi, A.; Cocconcelli, P.S. Surface microbiota analysis of Taleggio, Gorgonzolla, Casera, Scimudin and Fromaggio di Fossa Italian cheeses. Int. J. Food Microbiol. 2010, 138, 205-211. [CrossRef] [PubMed]

130. Morandi, S.; Silvetti, T.; Lopez, M.L.; Brasca, M. Antimicrobial activity, antibiotic resistance and the safety of lactic acid bacteria in raw milk Valtellina Casera cheese. J. Food Saf. 2015, 35, 193-205. [CrossRef]

131. Mangia, N.P.; Fancello, F.; Deiana, P. Microbiological characterization using combined culture dependent and independent approaches of Casizolu pasta filata cheese. J. Appl. Microbiol 2015, 120, 329-345. [CrossRef] [PubMed] 
132. Ryssel, M.; Johansen, P.; Al-Soud, W.A.; Sørensen, S.; Arneborg, N.; Jespersen, L. Microbial diversity and dynamics throughout manufacturing and ripening of surface ripened semi-hard Danish Danbo cheeses investigated by culture-independent techniques. Int. J. Food Microbiol. 2015, 215, 124-130. [CrossRef] [PubMed]

133. Bozoudi, D.; Torriani, S.; Zdragas, A.; Litopoulou-Tzanetaki, E. Assessment of microbial diversity of the dominant microbiota in fresh and mature PDO Feta cheese made at three mountainous areas of Greece. LWT Food Sci. Technol. 2016, 72, 525-533. [CrossRef]

134. Dolci, P.; De Filippis, F.; La Storia, A.; Ercolini, D.; Cocolin, L. rRNA-based monitoring of the microbiota involved in Fontina PDO cheese production in relation to different stages of cow lactation. Int. J. Food Microbiol. 2014, 185, 127-135. [CrossRef] [PubMed]

135. Senini, L.; Cappa, F.; Cocconcelli, P.S. Use of rRNA-targeted oligonucleotide probes for the characterization of the microflora from fermentation of Fontina cheese. Food Microbiol. 1997, 14, 469-476. [CrossRef]

136. Barbieri, E.; Schiavano, G.F.; De Santi, M.; Vallorani, L.; Casadei, L.; Guescini, M.; Gioacchini, A.M.; Rinaldi, L.; Stocchi, V.; Brandi, G. Bacterial diversity of traditional Fossa (pit) cheese and its ripening environment. Int. Dairy J. 2012, 23, 62-67. [CrossRef]

137. Pavunc, A.L.; Beganović Kos, B.; Uroić, K.; Blažić, M.; Šušković, J. Characterization and application of autochthonous starter cultures for fresh cheese production. Food Technol. Biotechnol. 2012, 50, 141-151.

138. Gonzalez, L.; Sacristán, N.; Arenas, R.; Fresno, J.M.; Tornadijo, M.E. Enzymatic activity of lactic acid bacteria (with antimicrobial properties) isolated from a traditional Spanish cheese. Food Microbiol. 2010, 27, 592-597. [CrossRef] [PubMed]

139. Van Hoorde, K.; Heyndrickx, M.; Vandamme, P.; Huys, G. Influence of pasteurization, brining conditions and production environment on the microbiota of artisan Gouda-type cheeses. Food Microbiol. 2010, 27, 425-433. [CrossRef] [PubMed]

140. Delcenserie, V.; Taminiau, B.; Delhalle, L.; Nezer, C.; Doyen, P.; Crevecoeur, S.; Roussey, D.; Korsak, N.; Daube, G. Microbiota characterization of a Belgian protected designation of origin cheese, Herve cheese, using metagenomic analysis. J. Dairy Sci. 2014, 97, 6046-6056. [CrossRef]

141. Fuka, M.M.; Engel, M.; Skelin, M.; Redžepović, S.; Schloter, M. Bacterial communities associated with the production of artisanal Istrian cheese. Int. J. Food Microbiol. 2010, 142, 19-24. [CrossRef] [PubMed]

142. Nieto-Arribas, P.; Seseña, S.; Poveda, J.M.; Chicón, R.; Cabezas, L.; Palop, L. Enterococcus populations in artisanal Manchego cheese: Biodiversity, technological and safety aspects. Food Microbiol. 2011, 28, 891-899. [CrossRef] [PubMed]

143. Nacef, M.; Chevalier, M.; Chollet, S.; Drider, D.; Flahaut, C. MALDI-TOF mass spectrometry for the identification of lactic acid bacteria isolated from a French cheese: The Maroilles. Int. J. Food Microbiol. 2017, 247, 2-8. [CrossRef]

144. Morea, M.; Baruzzi, F.; Cocconcelli, P.S. Molecular and physiological characterization of dominant bacterial populations in traditional Mozzarella cheese processing. J. Appl. Microbiol. 1999, 87, 574-582. [CrossRef]

145. Alegría, Á.; Szczesny, P.; Mayo, N.; Barodowski, J.; Kowalczyk, M. Biodiversity in Oscypek, a traditional Polish cheese, determined by culture-dependent and -independent approaches. Appl. Environ. Microbiol. 2012, 78, 1890-1898. [CrossRef]

146. Aquilanti, L.; Silvestri, G.; Zannini, E.; Osimani, A.; Santarelli, S.; Clementi, F. Phenotypic, genotypic and technological characterization of predominant lactic acid bacteria in Pecorino cheese from central Italy. J. Appl. Microbiol. 2007, 103, 948-960. [CrossRef]

147. De Pasquale, I.; Di Cagno, R.; Buchin, S.; De Angelis, M.; Gobbetti, M. Use of autochthonous mesophilic lactic acid bacteria as starter cultures for making Pecorino Crotonese cheese: Effect on compositional, microbiological and biochemical attributes. Food Res. Int. 2019, 116, 1344-1356. [CrossRef] [PubMed]

148. Russo, N.; Caggia, C.; Pino, A.; Coque, T.M.; Aroli, S.; Randazzo, C.L. Enterococcus spp. in Ragusano PDO and Pecorino Siciliano cheese types: A snapshot of their antibiotic resistance distribution. Food Chem. Toxicol. 2018, 120, 277-286. [CrossRef] [PubMed]

149. Freitas, A.C.; Pais, C.; Malcata, F.X.; Hogg, T.A. Microbiological characterization of Picante da Beira Baixa cheese. J. Food Prot. 1996, 59, 155-160. [CrossRef] [PubMed]

150. Freitas, A.C.; Pintado, A.E.; Manuela, E.P.; Malcata, F.X. Role of dominant microflora of Picante cheese on proteolysis and lipolysis. Int. Dairy J. 1999, 9, 593-603. [CrossRef]

151. Freitas, A.C.; Fresno, J.M.; Prieto, B.; Franco, I.; Malcata, F.X.; Carballo, J. How milk type, coagulant, salting procedure and ripening time affect the profile of free amino acids in Picante da Beira Baixa cheese. J. Sci. Food Agric. 1999, 79, 611-618. [CrossRef]

152. Câmara, S.P.A.; Dapkevicius, A.; Silva, C.C.G.; Malcata, F.X.; Dapkevicius, M.L.N.E. Artisanal Pico cheese as reservoir of Enterococcus species possessing virulence and antibiotic resistance properties: Implications for food safety. Food Biotechnol. 2020, 34, 25-41. [CrossRef]

153. Domingos-Lopes, M.F.P.; Stanton, C.; Ross, P.R.; Dapkevicius, M.L.E.; Silva, C.C.G. Genetic diversity, safety and technological characterization of lactic acid bacteria isolated from artisanal Pico cheese. Food Microbiol. 2017, 63, 178-190. [CrossRef]

154. Ribeiro, S.C.; Coelho, M.C.; Todorov, S.D.; Franco, B.D.G.M.; Dapkevicius, M.L.E.; Silva, C.C.G. Technological properties of bacteriocin-producing lactic acid bacteria isolated from Pico cheese, an artisanal cow's milk cheese. J. Appl. Microbiol. 2014, 116, 573-585. [CrossRef]

155. Kongo, J.M.; Gomes, A.M.; Malcata, F.X.; McSweeney, P.H.L. Microbiological, biochemical and compositional changes during ripening of São Jorge-a raw milk cheese from the Azores (Portugal). Food Chem. 2009, 112, 131-138. [CrossRef]

156. Delbès, C.; Ali-Mandjee, L.; Montel, M.-C. Monitoring bacterial communities in raw-milk and cheese by culture-dependent and -independent $16 S$ rRNA gene-based analyses. Appl. Environ. Microbiol. 2007, 73, 1882-1891. [CrossRef] 
157. Duthoit, F.; Godon, J.-J.; Montel, M.C. Bacterial community dynamics during production of registered designation of origin Salers cheese as evaluated by $16 \mathrm{~S}$ rRNA gene single-strand conformation polymorphism analysis. Appl. Environ. Microbiol. 2003, 69, 3840-3848. [CrossRef] [PubMed]

158. Duthoit, F.; Tessier, L.; Montel, M.C. Diversity, dynamics and activity of bacterial populations in "Registered Designation of Origin" Salers cheese by single-stranded conformation polymorphism analysis of 16S rRNA genes. J. Appl. Microbiol. 2005, 98, 1198-1208. [CrossRef] [PubMed]

159. Duthoit, F.; Callon, C.; Tessier, L.; Montel, M.C. Relationship between sensorial characteristics and microbial dynamics in "Registered Designation of Origin" Salers cheese. Int. J. Food Microbiol. 2005, 103, 259-270. [CrossRef] [PubMed]

160. González, L.; Cuadrillero, A.F.; Castro, J.M.; Bernardo, A.; Tornadijo, M.E. Selection of lactic acid bacteria isolated from San Simón da Costa cheese (PDO) in order to develop an autochthonous starter culture. Adv. Microbiol. 2015, 5, 748-759. [CrossRef]

161. Ledina, T.; Golob, M.; Djordjević, J.; Magas, V.; Colovic, S.; Bulajic, S. MALDI-TOF mass spectrometry for the identification of Serbian artisanal cheeses microbiota. J. Consum. Prot. Food S 2018, 13, 309-314. [CrossRef]

162. Macedo, A.C.; Malcata, F.X.; Hogg, T.A. Microbiological profile in Serra ewes' cheese during ripening. J. Appl. Microbiol. 1995, 79, 1-11. [CrossRef]

163. Tavaria, F.K.; Tavares, T.G.; Silva-Ferreira, A.C.; Malcata, F.X. Contribution of coagulant and native microflora to the volatile fatty acid profile of an artisanal cheese. Int. Dairy J. 2006, 16, 886-894. [CrossRef]

164. Ercolini, D.; Hill, P.J.; Dodd, C.E.R. Bacterial community structure and location in Stilton cheese. Appl. Environ. Microbiol. 2003, 69, 3540-3548. [CrossRef]

165. Pimentel, L.L.; Semedo, T.; Tenreiro, R.; Crespo, M.T.B.; Pintado, M.M.; Malcata, F.X. Assessment of safety of enterococci isolated throughout traditional Terrincho cheesemaking: Virulence factors and antibiotic susceptibility. J. Food Prot. 2007, 70, $2161-2167$. [CrossRef]

166. Majhenic, A.Č.; Rogelj, I.; Perko, B. Enterococi from Tolminc cheese: Population structure, antibiotic susceptibility and incidence of virulence determinants. Int. J. Food Microbiol. 2005, 102, 239-244. [CrossRef]

167. Fortina, M.G.; Ricci, G.; Acquati, A.; Zeppa, G.; Gandini, A.; Manachini, P.L. Genetic characterization of some lactic acid bacteria occurring in an artisanal protected denomination origin (PDO) Italian cheese, the Toma piemontese. Food Microbiol. 2003, 20, 397-404. [CrossRef]

168. Terzic-Vidojevic, A.; Tolinacki, M.; Nikolic, M.; Vejovic, K.; Jovanovic, S.; Macej, O.; Topisirovic, L. Artisanal Vlasina raw goat's milk cheese: Evaluation and selection of autochthonous lactic acid bacteria as starter cultures. Food Technol. Biotechnol. 2013, 51, 554-563.

169. Golić, N.; Čadež Terzić-Vidojević, A.; Šuranská, H.; Begnović, J.; Lozo, J.; Kos, B.; Šušković, J.; Raspor, P.; Topisirović, L. Evaluation of lactic acid bacteria and yeast diversity in traditional white pickled and fresh soft cheeses from the mountain regions of Serbia and lowland regions of Croatia. Int. J. Food Microbiol. 2013, 166, 294-300. [CrossRef] [PubMed]

170. Veljovic, K.; Terzic-Vidojevic, A.; Vukasinovic, M.; Strahinic, I.; Begovic, J.; Lozo, J.; Ostojic, M.; Topisirovic, L. Preliminary characterization of lactic acid bacteria isolated from Zlatar cheese. J. Appl. Microbiol. 2007, 103, 2141-2152. [CrossRef]

171. Yerlikaya, O.; Akbulut, N. Potential use of probiotic Enterococcus faecium and Enterococcus durans strains in Izmir Tulum cheese as adjunct culture. J. Food Sci. Technol. 2019, 56, 2175-2185. [CrossRef] [PubMed]

172. Malek, R.; El-Attar, A.; Mohamed, M.; Anwar, S.; El-Soda, M.; Béal, C. Technological and safety properties display biodiversity among enterococci isolated from two Egyptian cheeses, "Ras" and "Domiati". Int. J. Food Microbiol. 2012, 153, 314-322. [CrossRef] [PubMed]

173. Mc Sweeney, P.L.H. Biochemistry of cheese ripening. Int. J. Dairy Technol 2004, 57, 127-144. [CrossRef]

174. Câmara, S.P.A.; Dapkevicius, A.; Riquelme, C.; Elias, R.B.; Silva, C.C.G.; Malcata, F.X.; Dapkevicius, M.L.N.E. Potential of lactic acid bacteria from Pico cheese for starter culture development. Food Sci. Technol. Int. 2019, 25, 303-317. [CrossRef]

175. Serio, A.; Chaves-López, C.; Paparella, A.; Suzzi, G. Evaluation of metabolic activities of enterococci isolated from Pecorino Abruzzese cheese. Int. Dairy J. 2010, 20, 459-464. [CrossRef]

176. Andrighetto, C.; Knijff, E.; Lombardi, A.; Torriani, S.; Vancanneyt, M.; Kersters, K.; Swings, J.; Dellaglio, F. Phenotypic and genetic diversity of enterococci isolated from Italian cheeses. J. Dairy Res. 2001, 68, 303-316. [CrossRef]

177. Durlu-Ozkaya, F.; Xanthopoulous, V.; Tunail, N.; Litopoulou-Tzanetaki, E. Technologically important properties of lactic acid bacteria isolates from Beyaz cheese made from raw ewes' milk. J. Appl. Microbiol. 2001, 91, 861-870. [CrossRef]

178. Sarantinopoulos, P.; Andrighetto, C.; Gerogalaki, M.D.; Rea, M.C.; Lombardi, A.; Cogan, T.M.; Kalantzopoulos, G.; Tsakalidou, E. Biochemical properties of enterococci relevant to their technological performance. Int. Dairy J. 2001, 11, 621-647. [CrossRef]

179. Morandi, S.; Brasca, M.; Andrighetto, C.; Lombardi, A.; Lodi, R. Technological and molecular characterization of enterococci isolated from north-west Italian dairy products. Int. Dairy J. 2006, 16, 867-875. [CrossRef]

180. Margalho, L.P.; Schalkwijk, S.; Bachmann, H.; Sant'Ana, A.A. Enterococcus spp. in Brazilian artisanal cheeses: Occurrence and assessment of phenotypic and safety properties of a large set of strains through the use of high throughput tools combined with multivariate statistics. Food Control 2020, 118, 107425. [CrossRef]

181. Dagdemir, E.; Ozdemir, S. Technological characterization of the natural lactic acid bacteria of artisanal Turkish White Pickled cheese. Int. J. Dairy Technol. 2008, 61, 133-140. [CrossRef]

182. Tuncer, Y. Some technological properties of phenotypically identified enterococci strains isolated from Turkish Tulum cheese. Afr. J. Biotechnol. 2009, 8, 7008-7016. 
183. Gútiez, L.; Gómez-Sala, B.; Recio, I.; Del Campo, R.; Cintas, L.M.; Herranz, C.; Hernández, P.E. Enterococcus faecalis strains from food, environmental and clinical origin produce ACE-inhibitory peptides and other bioactive peptides during growth in bovine skim milk. Int. J. Food Microbiol. 2013, 166, 93-101. [CrossRef] [PubMed]

184. Van Tyne, D.; Gilmore, M.S. Friend turned foe: Evolution of enterococcal virulence and antibiotic resistance. Ann. Rev. Microbiol. 2014, 68, 337-356. [CrossRef] [PubMed]

185. Christensen, J.E.; Dudley, E.G.; Pederson, A.; Steele, J.L. Peptidases and amino acid catabolism in lactic acid bacteria. Antonie van Leeuwenhoek 1999, 76, 217-246. [CrossRef]

186. Olvera-García, M.; Sanchez-Flores, A.; Baruch, M.Q. Genomic and functional characterization of two Enterococcus strains isolated from Cotija cheese and their potential role in ripening. Appl. Microbiol. Biotechnol. 2018, 102, 2251-2267. [CrossRef]

187. Barbieri, F.; Montanari, C.; Gardini, F.; Tabanelli, G. Biogenic amine production by lactic acid bacteria: A review. Foods $2019,8,17$. [CrossRef]

188. Mc Donnell, M.; Fitzgerald, R.; Fhaoláin, I.N.; Jennings, V.; O'Cuinn, G. Purification and characterization of aminopeptidase P from Lactococcus lactis subsp. cremoris. J. Dairy Res. 1997, 64, 399-407. [CrossRef] [PubMed]

189. Perin, L.M.; Belviso, S.; Dal Bello, B.; Nero, L.A.; Cocolin, L. Technological properties and biogenic amines production by bacteriocinogenic lactococci and enterococci strains isolated from raw goat's milk. J. Food Prot. 2017, 80, 151-157. [CrossRef] [PubMed]

190. Lortal, S.; Chapot-Chartier, M.-P. Role, mechanisms and control of lactic acid bacteria lysis in cheese. Int. Dairy J. 2005, 15, 857-871. [CrossRef]

191. El-Din, B.B.; El-Soda, M.; Ezzat, N. Proteolytic, lipolytic and autolytic activities of enterococci strains isolated from Egyptian dairy products. Lait 2002, 82, 289-304. [CrossRef]

192. Gardiner, G.E.; Ross, P.R.; Wallace, J.M.; Scanlan, F.P.; Jägers, P.P.J.M.; Fitzgerald, F.F.; Collins, J.K.; Stanton, C. Influence of a probiotic adjunct culture of Enterococcus faecium on the quality of Cheddar cheese. J. Agric. Food Chem. 1999, 47, 4907-4916. [CrossRef]

193. Fortina, M.G.; Ricci, G.; Borgo, F.; Manachini, P.L.; Arends, K.; Schiwon, K.; Abajy, M.Y.; Grohmann, E. A survey on biotechnological potential and safety of the novel Enterococcus species of dairy origin, E. italicus. Int. J. Food Microbiol. 2008, 204-211. [CrossRef] [PubMed]

194. Irlinger, F.; Helinck, S.; Jany, J.L. Chapter 11-Secondary and adjunct cultures. In Cheese, 4th ed.; McSweeney, P.L.H., Fox, P.F.F., Cotter, P.D., Everett, D.W., Eds.; Academic Press: Cambridge, MA, USA, 2017; pp. 273-300.

195. Lynch, K.M.; Zannini, E.; Coffey, A.; Arendt, E.K. Lactic acid bacteria exopolysaccharides in foods and beverages: Isolation, properties, characterization and health benefits. Annu. Rev. Food Sci. Technol. 2018, 9, 155-176. [CrossRef]

196. Quintans, N.G.; Blancato, V.; Repizo, G.; Magni, C.; López, P. Citrate metabolism and aroma compound production in lactic acid bacteria. In Molecular Aspects of Lactic Acid Bacteria for Traditional and New Applications; Mayo, B., López, P., Pérez-Martínez, G., Eds.; Research Signpost: Kerala, India, 2008; pp. 65-88.

197. Sarantinopoulos, P.; Kalantzpoulos, G.; Tsakalidou, E. Effect of Enterococcus faecium on microbiological, physicochemical and sensory characteristics of Greek Feta cheese. Int. J. Food Microbiol. 2002, 76, 93-105. [CrossRef]

198. Abeijón, M.C.; Medina, R.B.; Katz, M.B.; González, S.N. Technological properties of Enterococcus faecium isolated from ewe's milk and cheese with importance for flavour development. Can. J. Microbiol. 2006, 52, 237-245. [CrossRef]

199. Martino, G.P.; Espariz, M.; Nizo, G.G.; Esteban, L.; Blancato, V.S.; Magni, C. Safety assessment and functional properties of four enterococci strains isolated from regional Argentinean cheese. Int. J. Food Microbiol. 2018, 277, 1-9. [CrossRef]

200. Arena, M.P.; Capozzi, V.; Spano, G.; Fiocco, D. The potential of lactic acid bacteria to colonize biotic and abiotic surfaces and the investigation of their interactions and mechanisms. Appl. Microbiol. Biotechnol. 2017, 101, 2641-2657. [CrossRef]

201. Mende, S.; Rohm, H.; Jaros, D. Influence of exopolysaccharides on the structure, texture, stability and sensory properties of yoghurt and related products. Int. Dairy J. 2016, 52, 57-71. [CrossRef]

202. Mozzi, F.; Vaningelgem, F.; Hébert, E.M.; Van der Meulen, R.; Foulquié Moreno, M.R.; Valdez, G.F.; De Vuyst, L. Diversity of heteropolysaccharide-producing lactic acid bacterium strains and their biopolymers. Appl. Environ. Microbiol. 2006, 72, 4431-4435. [CrossRef]

203. Özkan, E.R.; Demirci, T.; Akin, N. In vitro assessment of probiotic and virulence potential of Enterococcus faecium strains derived from artisanal goatskin casing Tulum cheeses produced in central Taurus Mountains of Turkey. LWT Food Sci. Technol. 2021, 141, 110908. [CrossRef]

204. Constantino, G.; Calasso, M.; Minervini, F.; De Angelis, M. Use of exopolysaccharide-synthesizing lactic acid bacteria and fat replacers for manufacturing reduced-fat Burrata cheese: Microbiological aspects and sensory evaluation. Microorganisms 2020, 8 , 1618. [CrossRef] [PubMed]

205. Yerlikaya, O.; Akpinar, A.; Saygili, D. Analysis of some physicochemical, rheological, sensorial properties, and probiotic viability of fermented milks containing Enterococcus faecium and Enterococcus durans strains. J. Food Process. Preserv. 2020, 44 , e14553. [CrossRef]

206. Cleveland, J.; Montville, T.J.; Nes, I.F.; Chikindas, M.L. Bacteriocins: Safe, natural antimicrobials for food preservation. Int. J. Food Microbiol. 2001, 71, 1-20. [CrossRef]

207. Javed, A.; Masud, T.; ul Ain, Q.; Imran, M.; Maqsood, S. Enterocins of Enterococcus faecium, emerging natural food preservatives. Ann. Microbiol. 2011, 61, 699-708. [CrossRef] 
208. Nilsen, T.; Nes, I.F.; Holo, H.; Enterolysin, A. A cell wall-degrading bacteriocin from Enterococcus faecalis LMG 2333. Appl. Environ. Microbiol. 2003, 69, 2975-2984. [CrossRef]

209. Oumer, A.; Gaya, P.; Fernández-García, E.; Mariaca, R.; Garde, S.; Medina, M.; Nuñez, M. Proteolysis and formation of volatile compounds in cheese manufactured with a bacteriocin-producing adjunct culture. J. Dairy Res. 2001, 68, 117-129. [CrossRef]

210. Ávila, M.; Garde, S.; Medina, M.; Nuñez, M. Effect of milk inoculation with bacteriocin-producing lactic acid bacteria on a Lactobacillus helveticus adjunct cheese culture. J. Food Prot. 2005, 78, 1026-1033. [CrossRef]

211. Silva, C.C.G.; Silva, S.P.M.; Ribeiro, S.C. Application of bacteriocins and protective cultures in dairy food preservation. Front. Microbiol. 2018, 9, 594. [CrossRef] [PubMed]

212. Aspri, M.; O'Connor, P.M.; Field, D.; Cotter, P.D.; Ross, P.; Hill, C.; Papademas, P. Application of bacteriocin-producing Enterococcus faecium isolated from donkey milk, in the bio-control of Listeria monocytogenes in fresh whey cheese. Int. Dairy J. 2017, 73, 1-9. [CrossRef]

213. Vandera, E.; Lianou, A.; Kakouri, A.; Feng, J.; Kokkou, A.-I.; Samelis, J. Enhanced control of Listeria monocytogenes by Enterococcus faecium KE82, a multiple enterocin-producing strain, in different milk environments. J. Food Prot. 2017, 80, 74-85. [CrossRef] [PubMed]

214. Ribeiro, S.C.; Ross, R.P.; Stanton, C.; Silva, C.C.G. Characterization and application of antilisterial enterocins on model fresh cheese. J. Food Prot. 2017, 80, 1303-1316. [CrossRef] [PubMed]

215. Muñoz, A.; Maqueda, M.; Gálvez, A.; Martínez-Bueno, M.; Rodríguez, A.; Valdivia, E. Biocontrol of psychrotrophic enterotoxigenic Bacillus cereus in a nonfat hard cheese by an enterococcal strain producing enterocin AS-48. J. Food Prot. 2004, 67, 1517-1521. [CrossRef]

216. Golob, M.; Pate, M.; Kušar, D.; Dermota, U.; Avberšek, J.; Papić, B.; Zdvoc, I. Antimicrobial resistance and virulence genes in Enterococcus faecium and Enterococcus faecalis from humans and retail red meat. BioMed Res. Int. 2019, 2019, 2815279. [CrossRef]

217. Cui, P.; Feng, L.; He, J.; An, T.; Fu, X.; Li, C.; Zhao, X.; Zhai, Y.; Li, H.; Yan, W.; et al. Antimicrobial resistance, virulence genes and biofilm formation capacity among Enterococcus species from Yaks in Aba Tibetan Autonomous Prefecture, China. Front. Microbiol. 2020, 11, 1250. [CrossRef]

218. Rahmeh, R.; Akbar, A.; Kishk, M.; Al Onaizi, T.; Al-Shatti, A.; Shajan, A.; Akbar, B.; Al-Mutairi, S.; Yateem, A. Characterization of semipurified enterocins produced by Enterococcus faecium strains isolated from raw camel milk. J. Dairy Sci. 2018, 101, 4944-4952. [CrossRef]

219. García-Solache, M.; Rice, L.B. The Enterococcus: A model of adaptability to its environment. Clin. Microbiol. Rev. 2019, 32, e00058-18. [CrossRef]

220. Korhonen, H. Milk-derived bioactive peptides: From science to applications. J. Funct. Foods 2009, 1, 177-187. [CrossRef]

221. Gútiez, L.; Borrero, J.; Jiménez, J.J.; Gómez-Sala, B.; Recio, I.; Cintas, L.M.; Herranz, C.; Hernández, P.E. Genetic and biochemical evidence that recombinant Enterococcus spp. strains expressing gelatinase (GelE) produce bovine milk-derived hydrolysates with high angiotensin converting-enzyme-inhibitory activity. J. Agric. Food Chem. 2014, 62, 5555-5564. [CrossRef] [PubMed]

222. Regazzo, D.; Da Dalt, L.; Lombardi, A.; Andrighetto, C.; Negro, A.; Gabai, G. Fermented milks from Enterococcus faecalis TH563 and Lactobacillus delbrueckii subsp. Bulgaricus LA2 manifest different degrees of ACE-inhibitory and immunomodulatory activities. Dairy Sci. Technol. 2010, 90, 469-476. [CrossRef]

223. Muguerza, B.; Ramos, M.; Sánchez, E.; Manso, M.A.; Miguel, M.; Aleixandre, A.; Delgado, M.A.; Recio, I. Antihypertensive activity of milk fermented by Enterococcus faecalis strains isolated from raw milk. Int. Dairy J. 2006, 26, 61-69. [CrossRef]

224. Quirós, A.; Ramos, M.; Muguerza, B.; Delgado, M.A.; Miguel, M.; Aleixandre, A.; Recio, I. Identification of novel antihypertensive peptides in milk fermented with Enterococcus faecalis. Int. Dairy J. 2007, 17, 33-41. [CrossRef]

225. Torres-Llanez, M.J.; González-Córdova, A.F.; Hernandez-Mendoza, A.; Garcia, H.S. Angiotensin-converting enzyme inhibitory activity in Mexican Fresco cheese. J. Dairy Sci. 2011, 94, 3794-3800. [CrossRef] [PubMed]

226. Nilsen, R.; Pripp, A.H.; Høstmark, A.T.; Haug, A.; Skeie, S. Is consumption of a cheese rich in angiotensin-converting enzymeinhibiting peptides, such as the Norwegian cheese Gamalost, associated with reduced blood pressure? J. Dairy Sci. 2014, 97, 2662-2668. [CrossRef]

227. Baptista, D.P.; Gigante, M.L. Bioactive peptides in ripened cheeses: Release during technological processes and resistance to the gastrointestinal tract. J. Sci. Food Agri. 2021. [CrossRef]

228. Martini, S.; Conte, A.; Tagliazucchi, D. Effect of ripening and in vitro digestion on the evolution and fate of bioactive peptides in Parmigiano-Reggiano cheese. Int. Dairy J. 2020, 105, 104668. [CrossRef]

229. Lu, Y.; Govindasamy-Lucey, S.; Lucey, J.A. Angiotensin-I-converting enzyme-inhibitory peptides in commercial Wisconsin Cheddar cheeses of different ages. J. Dairy Sci. 2016, 99, 41-52. [CrossRef]

230. O'Shea, E.F.; Cotter, P.D.; Stanton, C.; Ross, P.R.; Hill, C. Production of bioactive substances by intestinal bacteria as a basis for explaining probiotic mechanisms: Bacteriocins and conjugated linoleic acid. Int. J. Food Microbiol. 2012, 152, 189-205. [CrossRef]

231. Zhu, Y.; Li, T.; Ud Din, A.; Hassan, A.; Wang, Y.; Wang, G. Beneficial effects of Enterococcus faecalis in hypercholesterolemic mice on cholesterol transportation and gut microbiota. Appl. Microbiol. Biotechnol. 2019, 103, 3181-3191. [CrossRef] [PubMed]

232. Huang, F.; Zhang, F.; Xu, D.; Zhang, Z.; Xu, F.; Tao, X.; Qiu, L.; Wei, H. Enterococcus faecium WEFA23 from infants lessens high-fat diet-induced hyperlipidemia via cholesterol 7-alpha-hydroxylase gene by altering the composition of gut microbiota in rats. J. Dairy Sci. 2018, 101, 7757-7767. [CrossRef] [PubMed] 
233. Albano, C.; Morandi, S.; Silvetti, T.; Casiraghi, M.C.; Manini, F.; Brasca, M. Lactic acid bacteria with cholesterol-lowering properties for dairy applications: In vitro and in situ activity. J. Dairy Sci. 2018, 101, 10807-10818. [CrossRef] [PubMed]

234. Zhang, F.; Qiu, L.; Liu, Z.; Zhan, H.; Tao, X.; Shah, N.; Wei, H. Beneficial effects of probiotic cholesterol-lowering strain of Enterococcus faecium WEFA23 from infants on diet-induced metabolic syndrome in rats. J. Dairy Sci. 2017, 100, 1618-1628. [CrossRef] [PubMed]

235. Baccouri, O.; Boukerb, A.M.; Ben Farhat, L.; Zébré, A.; Zimmerman, K.; Domann, E.; Cambronel, M.; Barreau, M.; Maillot, O.; Rincé, I.; et al. Probiotic potential and safety evaluation of Enterococcus faecalis OB14 and OB15, isolated from traditional Tunisian Testouri cheese and Rigouta, using physiological and genomic analysis. Front. Microbiol. 2019, 10, 881. [CrossRef] [PubMed]

236. Andrade, J.; Ascenção, K.; Gullón, P.; Henriques, S.M.S.; Pinto, J.M.S.; Rocha-Santos, T.A.P.; Freitas, A.C.; Gomes, A.M. Production of conjugated linoleic acid by food-grade bacteria: A review. Int. J. Dairy Technol. 2012, 65, 467-481. [CrossRef]

237. Kishino, S.; Ogawa, J.; Omura, Y.; Matsumura, K.; Shimizu, S. Conjugated linoleic acid production from linoleic acid by lactic acid bacteria. J. Am. Oil Chem. Soc. 2002, 79, 159-163. [CrossRef]

238. Ross, R.P.; Stanton, C.; Hill, C.; Fitzgeral, G.F.; Coffey, A. Novel cultures for cheese improvement. Trends Food Sci. Technol. 2000, 11, 96-104. [CrossRef]

239. Del Toro-Barbosa, M.; Hurtado-Romero, A.; Garcia-Amezquita, L.E.; Carcía-Cayuela, T. Psychobiotics: Mechanisms of action, evaluation methods and effectiveness in applications with food products. Nutrients 2020, 12, 3896. [CrossRef] [PubMed]

240. Cryan, J.F.; Dinan, T.G. Mind-altering microorganisms: The impact of the gut microbiota on brain and behaviour. Nat. Rev. 2012, 13, 701-710. [CrossRef]

241. Santos-Espinosa, A.; Beltrán-Barrientos, L.M.; Reyes-Díaz, R.; Mazorra-Manzano, M.A.; Hernández-Mendoza, A.; GonzálezAguilar, G.A.; Sayago-Ayerdi, S.G.; Vallejo-Cordoba, B.; González-Cárdova, A.F. Gamma-aminobutyric acid (GABA) production in milk fermented by specific wild lactic acid bacteria strains isolated from artisanal Mexican cheeses. Ann. Microbiol. 2020, 70, 12. [CrossRef]

242. Ribeiro, S.C.; Domingos-Lopes, M.F.P.; Stanton, C.; Ross, R.P.; Silva, C.C.G. Production of $\gamma$-aminobutyric acid (GABA) by Lactobacillus otakiensis and other Lactobacillus sp.isolated from traditional Pico cheese. Int. J. Dairy Technol. 2018, 70, 1-6. [CrossRef]

243. Saavedra, L.; Taranto, M.P.; Sesma, F.; de Valdez, G.M. Homemade traditional cheeses for the isolation of probiotic Enterococcus faecium strains. Int. J. Food Microbiol. 2003, 241-245. [CrossRef]

244. Nascimento, L.C.S.; Casarotti, S.N.; Todorov, S.D.; Penna, A.L.B. Probiotic potential and safety of enterococci strains. Ann. Microbiol. 2019, 69, 241-252. [CrossRef]

245. Hermanns, G.; Funck, G.D.; Schmidt, J.T.; Pereira, J.Q.; Brandelli, A.; Richards, N.S.P.S. Evaluation of probiotic characteristics of lactic acid bacteria isolated from artisan cheese. J. Food Saf. 2014, 34, 380-387. [CrossRef]

246. Wang, X.; Yang, Y.; Huycke, M.M. Risks associated with enterococci as probiotics. Food Res. Int. 2020, 129, 108788. [CrossRef]

247. Homayouni, A.; Ansari, F.; Azizi, A.; Pourjafar, H.; Madadi, M. Cheese as a potential food carrier to deliver probiotic microorganisms into the human gut: A review. Curr. Nutr. Food Sci. 2018, 14, 1-13. [CrossRef]

248. Castro, J.M.; Tornadijo, M.E.; Fresno, J.M.; Sandoval, H. Biocheese: A food probiotic carrier. BioMed Res. Int. 2015, $2015,723056$. [CrossRef] [PubMed]

249. Kayser, F.H. Safety aspects of enterococci from the medical point of view. Int. J. Food Microbiol. 2003, 88, 255-262. [CrossRef]

250. Mundy, L.M.; Sahm, D.F.; Gilmore, M. Relationships between enterococcal virulence and antimicrobial resistance. Clin. Microbiol. Rev. 2000, 13, 513-522. [CrossRef]

251. Mulani, M.S.; Kamble, E.E.; Kumkar, S.N.; Tawre, M.; Pardesi, K.R. Emerging strategies to combat ESKAPE pathogens in the era of antimicrobial resistance: A review. Front. Microbiol. 2019, 10, 539. [CrossRef] [PubMed]

252. Chajęcka-Wierzchowska, W.; Zadernowska, A.; Łaniewska-Trokenheim, Ł. Virulence factors of Enterococcus species presented in foods. LWT Food Sci. Technol. 2017, 75, 670-676. [CrossRef]

253. Lebreton, F.; Riboulet-Bisson, E.; Serror, P.; Sanguinetti, M.; Posteraro, B.; Torelli, R.; Hartke, A.; Auffray, Y.; Giard, J.-C. Ace, which encodes and adhesin in Enterococcus faecalis, is regulated by Ers and is involved in virulence. Infect. Immun. 2009, 77, 2832-2839. [CrossRef]

254. Vanek, N.N.; Simon, S.I.; Jacques-Palaz, K.; Mariscalco, M.M.; Dunny, G.M.; Rakita, R.M. Enterococcus faecalis aggregation substance promotes opsonin-independent binding to human neutrophils via a complement receptor type 3-mediated mechanism. FEMS Immunol. Med. Microbiol. 1999, 26, 49-60. [CrossRef]

255. Kayaoglu, G.; Østarvik, D. Virulence factors of Enterococcus faecalis: Relationship to endodontic disease. Crit. Rev. Oral Biol. Med. 2004, 15, 308-320. [CrossRef]

256. Süßmuth, S.D.; Muscholl-Silberhorn, A.; Wirth, R.; Susa, M.; Marre, R.; Rozdzinski, E. Aggregation substance promotes adherence, phagocytosis, and intracellular survival of Enterococcus faecalis within human macrophages and suppresses respiratory burst. Infect. Immun. 2000, 68, 4900-4906. [CrossRef] [PubMed]

257. Duprè, I.; Zanetti, S.; Schito, A.M.; Fadda, G.; Sechi, L.A. Incidence of virulence determinants in clinical Enterococcus faecium and Enterococcus faecalis isolates collected in Sardinia (Italy). J. Med. Microbiol. 2003, 52, 491-498. [CrossRef]

258. Elsner, H.-A.; Sobottka, I.; Mack, D.; Claussen, M.; Laufs, R.; Wirth, R. Virulence factors of Enterococcus faecalis and Enterococcus faecium blood culture isolates. Eur. J. Clin. Microbiol. Infect. Dis. 2000, 19, 39-42. [CrossRef] [PubMed] 
259. Coque, T.M.; Patterson, J.E.; Steckelberg, J.M.; Murray, B. Incidence of hemolysin, gelatinase, and aggregation substance among enterococci isolated from patients with endocarditis and other infections and from feces of hospitalized and community-based persons. Infect. Immun. 2004, 72, 2445-2448. [CrossRef]

260. Kim, S.-H.; Kim, D.-H.; Lim, H.-W.; Seo, K.-H. High prevalence of non-faecalis and non-faecium Enterococcus spp. in farmstead cheesehouse and their applicability as hygiene indicators. LWT Food Sci. Technol. 2020, 126, 109271. [CrossRef]

261. Nallapareddy, S.R.; Singh, K.V.; Duh, R.-W.; Weinstock, G.; Murray, B.E. Diversity of ace, a gene encoding a microbial surface component recognizing adhesive matrix molecules from different strains of Enterococcus faecalis and evidence for production of Ace during human infections. Infect. Immun. 2000, 68, 5210-5217. [CrossRef] [PubMed]

262. Franz, C.M.A.P.; Stiles, M.E.; Schleifer, K.H.; Holzapfel, W.H. Enterococci in foods, a conundrum for food safety. Int. J. Food Microbiol. 2003, 88, 105-122. [CrossRef]

263. Eaton, T.J.; Gasson, M.J. Molecular screening of Enterococcus virulence determinants and potential for genetic exchange between food and medical isolates. Appl. Environ. Microbiol. 2001, 67, 1628-1635. [CrossRef]

264. Toledo-Arana, A.; Valle, J.; Solano, C.; Arrizubieta, M.J.; Cucarella, C.; Lamata, M.; Amorena, B.; Leiva, J.; Penadés, J.R.; Lasa, I. The enterococcal surface protein, Esp, is involved in Enterococcus faecalis biofilm formation. Appl. Environ. Microbiol. 2001, 67, 4538-4545. [CrossRef] [PubMed]

265. Fux, C.A.; Costerton, J.W.; Stewart, P.S.; Stoodley, P. Survival strategies of infectious biofilms. Trends Microbiol. 2005, 13, 34-40. [CrossRef]

266. Leavis, H.; Top, J.; Shankar, N.; Borgen, K.; Bonten, M.; van Embden, J.; Willems, R.J. A novel putative pathogenicity Island linked to esp virulence gene of Enterococcus faecium and associated with epidemicity. J. Bacteriol. 2004, 186, 672-682. [CrossRef]

267. Ochoa, S.A.; Escalona, G.; Cruz-Cordova, A.; D’Ávila, L.B.; Saldana, Z.; Cázares-Domímguez, V.; Eslava, C.A.; López-Martínez, B.; Hernández-Castro, R.; Aquino-Jarquin, G.; et al. Molecular analysis and distribution of multidrugresistant Enterococcus faecium isolates belonging to clonal complex 17 in a tertiary care center in Mexico City. BMC Microbiol. 2013, 13, 291. [CrossRef]

268. Oancea, C.; Klare, I.; Witte, W.; Werner, G. Conjugative transfer of the virulence gene, esp, among isolates of Enterococcus faecium and Enterococcus faecalis. J. Antimicrob. Chemother. 2004, 54, 232-235. [CrossRef]

269. Ogier, J.-C.; Serror, P. Safety assessment of dairy microorganisms: The Enterococcus genus. Int. J. Food Microbiol. 2008, 126, 291-301. [CrossRef]

270. Vankerckhoven, V.; Van Autgaerden, T.; Vael, C.; Lammens, C.; Chapelle, S.; Rossi, R.; Jabes, D.; Goossens, H. Development of a multiplex PCR for the detection of asa1, gelE, cylA, esp, and hyl genes in enterococci and survey for virulence determinants among European hospital isolates of Enterococcus faecium. J. Clin. Microbiol. 2004, 42, 4473-4479. [CrossRef] [PubMed]

271. Jahansepas, A.; Sharifi, Y.; Aghazadeh, M.; Rezaee, M.A. Comparative analysis of Enterococcus faecalis and Enterococcus faecium strains isolated from clinical samples and traditional cheese types in the Northwest of Iran: Antimicrobial susceptibility and virulence traits. Archiv. Microbiol. 2020, 202, 756-772. [CrossRef] [PubMed]

272. Cariolato, D.; Andrighetto, C.; Lombardi, A. Occurrence of virulence factors and antibiotic resistances in Enterococcus faecalis and Enterococcus faecium collected from dairy and human samples in North Italy. Food Control 2008, 19, 886-892. [CrossRef]

273. Gaglio, R.; Couto, N.; Marques, C.; Lopes, M.F.S.; Moschetti, G.; Pomba, C.; Settani, L. Evaluation of antimicrobial resistance and virulence of enterococci from equipment surfaces, raw materials, and traditional cheeses. Int. J. Food Microbiol. 2016, 236, 107-114. [CrossRef]

274. Hammad, A.M.; Hassan, H.A.; Shimamoto, T. Prevalence, antibiotic resistance and virulence of Enterococcus spp. in Egyptian fresh raw milk cheese. Food Control 2015, 50, 815-820. [CrossRef]

275. İspirli, H.; Demirbaş, F.; Dertli, E. Characterization of functional properties of Enterococcus spp. Isolated from Turkish white cheese. LWT Food Sci. Technol. 2017, 75, 358-365. [CrossRef]

276. Fuka, M.M.; Maksimovic, A.Z.; Tanuwidjaja, I.; Hulak, N.; Schloter, M. Characterization of enterococcal community isolated from an artisan Istrian raw milk cheese: Biotechnological and safety aspects. Food Technol. Biotechnol. 2017, 55, 368-380. [CrossRef]

277. Cebrián, R.; Baños, A.; Valdivia, E.; Pérez-Pulido, R.; Martínez-Bueno, M.; Maqueda, M. Characterization of functional, safety, and probiotic properties of Enterococcus faecalis UGRA10, a new AS-48-producer strain. Food Microbiol. 2012, 30, 59-67. [CrossRef]

278. Templer, S.P.; Baumgartner, A. Enterococci from Appenzeller and Schabziger raw milk cheese: Antibiotic resistance, virulence factors, and persistence of particular strains in the products. J. Food Prot. 2007, 70, 450-455. [CrossRef]

279. Yuksel, F.N.; Akcelik, N.; Akcelik, M. Incidence of antibiotic resistance and virulence determinants in Enterococcus faecium and Enterococcus faecalis strains isolated from traditional cheeses in Turkey. Mol. Gen. Microbiol. Virol. 2015, 30, 206-215. [CrossRef]

280. Popović, N.; Dinić, M.; Tolinački, M.; Mihaljović, S.; Terzić-Vidojević, A.; Bojić, S.; Djokić, J.; Golić, N.; Veljović, K. New insight into biofilm formation ability, the presence of virulence genes and probiotic potential of Enterococcus sp. dairy isolates. Front. Microbiol. 2018, 9, 78. [CrossRef] [PubMed]

281. Chajęcka-Wierzchowska, W.; Zadernowska, A.; Zarzecka, U.; Zakrzewski, A.; Gajewska, J. Enterococci from ready-to-eat foodhorizontal gene transfer of antibiotic resistance genes and genotypic characterization by PCR melting profile. J. Sci. Food Agric. 2019, 99, 1172-1179. [CrossRef] [PubMed]

282. Fiore, E.; Van Tyne, D.; Gilmore, M.S. Pathogenicity of enterococci. Microbiol. Spectr. 2019, 7. [CrossRef]

283. Pillar, C.M.; Gilmore, M.S. Enterococcal virulence-pathogenicity island of E. faecalis. Front. BioSci. 2004, 9, 2335-2346. [CrossRef]

284. Ramos, S.; Silva, V.; Dapkevicius, M.L.N.E.; Igrejas, G.; Poeta, P. Enterococci, from harmless bacteria to a pathogen. Microorganisms 2020, 8, 1118. [CrossRef] 
285. Silvetti, T.; Capra, E.; Morandi, S.; Cremonesi, P.; Decimo, M.; Gavazzi, F.; Giannico, R.; De Noni, I.; Brasca, M. Microbial population profile during ripening of Protected Designation of Origin (PDO) Silter cheese, produced with and without autochthonous starter culture. LWT Food Sci. Technol. 2017, 84, 821-831. [CrossRef]

286. Barlow, S.; Chesson, A.; Collins, J.D.; Dybing, E.; Flynn, A.; Fruijtier-Pölloth, C.; Hardy, A.; Knapp, A.; Kuiper, H.; Le Neindre, P.; et al. Opinion of the Scientific Committee on a request from EFSA on the introduction of a Qualified Presumption of Safety (QPS) approach for assessment of selected microorganisms referred to EFSA. EFSA J. 2007, 587, 1-16. [CrossRef]

287. Miller, W.R.; Munita, J.M.; Arias, C.A. Mechanisms of antibiotic resistance in enterococci. Expert Rev. Anti Infect. Ther. 2014, 12, 1221-1236. [CrossRef]

288. Palmer, K.L.; Kos, V.N.; Gilmore, M.S. Horizontal gene transfer and the genomics of enterococcal antibiotic resistance. Curr. Opin. Microbiol. 2010, 13, 632-639. [CrossRef]

289. Hollenbeck, B.L.; Rice, L.B. Intrinsic and acquired resistance mechanisms in enterococcus. Virulence 2012, 3, 421-569. [CrossRef] [PubMed]

290. Sun, D.; Jeannot, K.; Xiao, Y.; Knapp, C.W. Horizontal gene transfer mediated bacterial antibiotic resistance. Front. Microbiol. 2019, 27, 933. [CrossRef] [PubMed]

291. Schroeder, M.; Brooks, B.D.; Brooks, A.E. The complex relationship between virulence and antibiotic resistance. Genes 2017, 8, 39. [CrossRef] [PubMed]

292. Clewell, D.; Weaver, K.; Dunny, G.; Coque, T.M.; Francia, M.V.; Hayes, F. Extrachromosomal and Mobile Elements in Enterococci: Transmission, Maintenance, and Epidemiology. In Enterococci: From Commensals to Leading Causes of Drug Resistant Infection [Internet]; Gilmore, M., Clewell, D.D.B., Ike, Y., Shankar, N., Eds.; Massachusetts Eye and Ear Infirmary: Boston, MA, USA, 2014; pp. 309-420.

293. Palmer, K.L.; Gilmore, M.S. Multidrug-resistant enterococci lack CRISPR-cas. mBio 2010, 12, e00227-10. [CrossRef]

294. Bonacina, J.; Suárez, N.; Hormigo, R.; Fadda, S.; Lechner, M.; Saavedra, L. A genomic view of food-related and probiotic Enterococcus strains. DNA Res. 2017, 24, 1-24. [CrossRef]

295. Ahmed, M.O.; Baptiste, K.E. Vancomycin-resistant enterococci: A review of antimicrobial resistance mechanisms and perspectives of human and animal health. Microb. Drug Resist. 2018, 24, 590-606. [CrossRef]

296. Agudelo Higuita, N.I.; Huycke, M.M. Enterococcal Disease, Epidemiology, and Implications for Treatment. In Enterococci: From Commensals to Leading Causes of Drug Resistant Infection; Gilmore, M.S., Clewell, D.B., Ike, Y., Shankar, N., Eds.; Massachusetts Eye and Ear Infirmary: Boston, MA, USA, 2014; pp. 65-100.

297. Maietti, L.; Bonvini, B.; Huys, G.; Giraffa, G. Incidence of antibiotic resistance and virulence determinants among Enterococcus italicus isolates from dairy products. Syst. Appl. Microbiol. 2007, 30, 509-517. [CrossRef]

298. Mannu, L.; Paba, A.; Daga, E.; Comunian, R.; Zanetti, S.; Duprè, I.; Sechi, L.A. Comparison of the incidence of virulence determinants and antibiotic resistance between Enterococcus faecium strains of dairy, animal and clinical origin. Int. J. Food Microbiol. 2003, 88, 291-304. [CrossRef]

299. WHO. World Health Organization Model List of Essential Medicines, 21st ed.; World Health Organization: Geneva, Switzerland, 2019.

300. Castaño-Arriba, A.; González-Machado, C.; Igrejas, G.; Poeta, P.; Alonso-Calleja, C.; Capita, R. Antibiotic resistance and biofilm-forming ability in enterococcal isolates from red meat and poultry preparations. Pathogens 2020, 9, 1021. [CrossRef] 